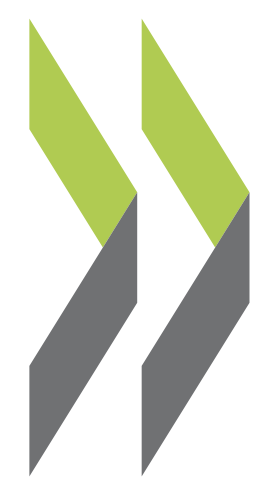

OECD Working Papers on International Investment 2017/05

Adjudicator Compensation Systems and Investor-State David Gaukrodger Dispute Settlement 


\section{OECD WORKING PAPERS ON INTERNATIONAL INVESTMENT}

OECD Working Papers should not be reported as representing the official views of the OECD or of its member countries. The opinions expressed and arguments employed are those of the authors.

Working Papers describe preliminary results or research in progress by the author(s) and are published to stimulate discussion on a broad range of issues on which the OECD works. Comments on Working Papers are welcomed, and may be sent to investment@oecd.org or the Investment Division Directorate for Financial and Enterprise Affairs, OECD, 2 rue André-Pascal, 75775 Paris Cedex 16, France.

The international investment working paper series - including policies and trends and the broader implications of multinational enterprise - is designed to make available to a wide readership selected studies by the OECD Investment Committee, OECD Investment Division staff, or by outside consultants working on OECD Investment Committee projects.

The papers are generally available only in their original language English or French with a summary in the other if available.

OECD WORKING PAPERS ON INTERNATIONAL INVESTMENT are published on www.oecd.org/daf/inv/investment-policy/working-papers.htm.

This document and any map included herein are without prejudice to the status of or sovereignty over any territory, to the delimitation of international frontiers and boundaries and to the name of any territory, city or area.

You can copy, download or print OECD content for your own use, and you can include excerpts from OECD publications, databases and multimedia products in your own documents, presentations, blogs, websites and teaching materials, provided that suitable acknowledgment of OECD as source and copyright owner is given. All requests for commercial use and translation rights should be submitted to rights@oecd.org. 


\title{
Adjudicator Compensation Systems and Investor-State Dispute Settlement
}

\author{
by \\ David Gaukrodger
}

\begin{abstract}
Compensation for adjudicators is generally considered as a core issue for judicial independence and for attracting good judges in the institutional design for courts. This paper examines compensation systems for adjudicators and dispute settlement administrators in investor-state dispute settlement (ISDS). The paper uses in part a comparative perspective based on approaches in domestic courts in advanced economies, an approach rarely taken in analysing investor-state arbitration.

The first section of the paper provides historical context and examines the reform of remuneration of judges to replace private litigant fees with salaries in colonial America and the United States, France and England in the $18^{\text {th }}$ and early $19^{\text {th }}$ centuries. Subsequent sections address debates over the impact of compensation systems on adjudicators; contemporary approaches to the compensation of judges in advanced economies; the co-existence in advanced economies of national courts with salaried judges since the early 19th century with generally strong support for commercial arbitration based on ad hoc fee-based remuneration; and similarities and differences between commercial arbitration and investment arbitration, focusing how the largely similar compensation systems may have different effects and be differently perceived by the public.

Annexes to the paper report on discussions about adjudicator compensation at the 2016 OECD Investment Treaty Conference and gather some preliminary facts about adjudicator and dispute administrator compensation in investor-state arbitration as well as the investment court system included in the recent EU-Canada CETA trade and investment agreement.
\end{abstract}

Approved by Pierre Poret, Director, OECD Directorate for Financial and Enterprise Affairs

JEL Classification: H4, J3, J33, J44, K23, K33, K41, L33, N4, N20

Keywords: investment treaties; bilateral investment treaties; investor protection; comparative law; legal history; Alexander Hamilton; Jeremy Bentham; Voltaire; investment treaty policy; dispute settlement; investor-state dispute settlement; ISDS; investment arbitration; international commercial arbitration; domestic courts; international economic law; litigant fees; court fees; conflicts of interest; judicial compensation; arbitrator compensation; economic incentives; foreign investment; international investment; international investment law; international investment agreements. 


\section{Table of Contents}

Executive summary

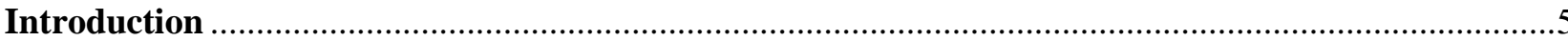

I. The historical evolution of judicial compensation from litigant fees to government salaries ......... 8

A. Eighteenth-century court systems and criticism of litigant fee-based compensation

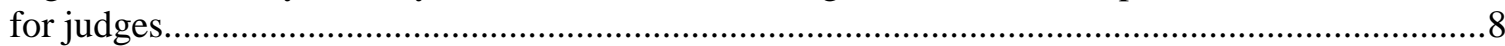

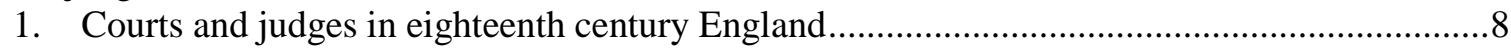

2. Criticism of litigant fees payable to judges and court officials in America and England.........9

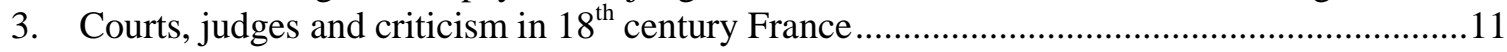

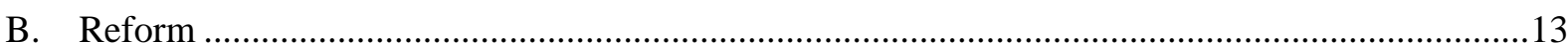

II. The debate over the impact of judicial compensation systems...................................................17

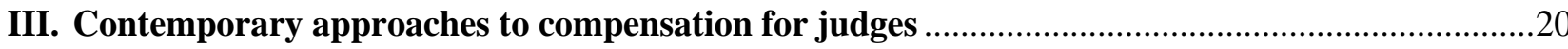

A. Stable government-paid salaries and other institutional arrangements ........................................20

B. Beyond providing for stable salaries and other institutional arrangements, governments apply additional rules to exclude the influence of pecuniary interests

IV. The co-existence of courts and commercial arbitration with different

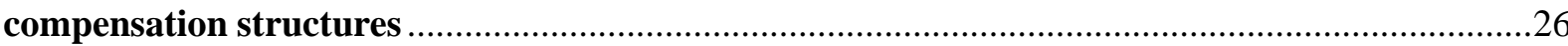

V. Commercial arbitration and investment treaty dispute settlement ...........................................28

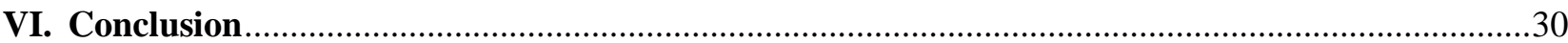

Annex 1: 2016 OECD Investment Treaty Conference discussion relating to adjudicator compensation

Annex 2: Preliminary review of facts relating to compensation of adjudicators and dispute

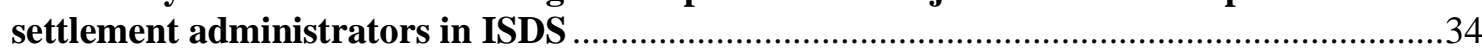

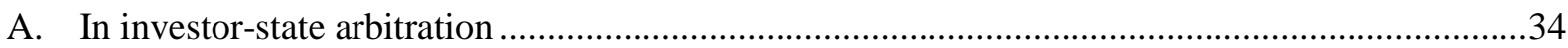

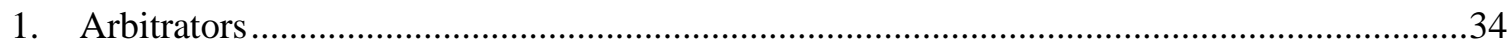

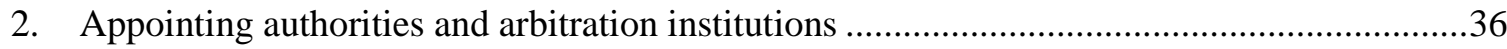

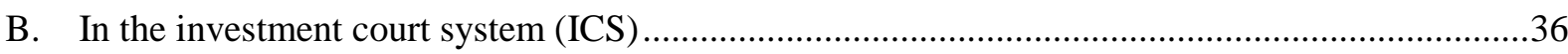




\section{Executive summary}

Adjudicator compensation in investor-state dispute settlement (ISDS) has been subject to limited analysis. It is rarely addressed in investment treaties or in existing guidelines on conflicts of interest in arbitration prepared by the arbitration bar. It has, however, become an important part of the public and policy debate over ISDS. Compensation for adjudicators is also generally considered as a core issue for judicial independence and for attracting good judges in good institutional design for courts.

This paper examines compensation systems for adjudicators and dispute settlement administrators in ISDS. It is widely recognised that the compensation system in investor-state arbitration has helped it achieve independence from host governments. But public criticism is accumulating on other issues and includes concerns about direct pecuniary interests in case outcomes, incentives to engage in lengthy and costly procedures, or an over-riding interest in future appointments due to the ad hoc nature of arbitral appointments. While many critiques allege pro-investor biases, possible incentives to preserve a lucrative investor-state arbitration system may at times be perceived by some to cut the other way to the detriment of certain investor claimants. New proposals in ISDS, such as the bilateral investment court system (ICS) included in the 2016 Comprehensive Economic and Trade Agreement (CETA) between Canada, the European Union and EU Member States, are also grappling with issues of adjudicator compensation.

The paper uses in part a comparative perspective based on approaches in domestic courts in advanced economies, an approach rarely taken in investor-state arbitration. While it expresses no view about the value of any particular benchmark, the paper suggests that domestic courts are likely to be an important point of reference for the public in evaluating investor-state arbitration both because they are known and because investor-state arbitration is often advanced as a solution to perceived weaknesses in domestic courts. The CETA Parties have recently expressly referred to their domestic courts as one model for ISDS.

The first section of the paper provides historical context. Remuneration of judges by private litigant fees was widely used to compensate judges in colonial America, France and England in the $18^{\text {th }}$ century. Litigant fees payable to judges were essentially abolished in all three between 1776 and 1825. Private payments to judges in individual cases were replaced by government salaries. Leading thinkers such as Voltaire, Alexander Hamilton and Jeremy Bentham advocated for the changes and the reforms are seen as fundamental features of the courts.

A second section considers the historical and contemporary debate over the impact of compensation systems on adjudicators. Leading thinkers have considered that compensation structures and the degree of claimant choice of courts have affected adjudication or can be expected to affect adjudication. The paper reports on a range of views about the impact of compensation systems on the behaviour of adjudicators and court officials, but it takes no position on the actual impact, if any, of economic interests in general or in particular cases. At the same time, it notes the widely-recognised importance of appearances in this context, as illustrated by Lord Hewart's well-known statement that "justice must not only be done, it must also be seen to be done".

The third section explores contemporary approaches to the compensation of judges in advanced economies. Common institutional arrangements for judges in senior courts include stable government salaries; remuneration solely from the government rather than from litigants; disclosure of salaries to the public; limits on remuneration from other sources and outside activities; and appointment for life or for significant fixed terms with a possibility of re-appointment.

$1 \quad$ R. v. Sussex Justices, Ex parte McCarthy ([1924] 1 KB 256. 
A fourth section explores the co-existence in advanced economies of national courts with salaried judges since the early 19th century with generally strong support for commercial arbitration based on ad hoc fee-based remuneration. It suggests that co-existence may have been eased by (i) limited exposure to commercial arbitration of public entities and governments in advanced economies; (ii) findings that a party agreeing to commercial arbitration has waived its claim to object to certain pecuniary interests in adjudicators; and (iii) the bilateral nature of agreement to commercial arbitration in which both parties agree to waive their access to the courts, but both parties also agree to subject themselves to claims in arbitration.

A final section compares commercial arbitration with investment arbitration, focusing how the largely similar compensation systems may have different effects and be differently perceived by the public. Relatively little information is made publicly available about compensation under either arbitration system, with the exception of the ICSID USD 3000 cap on daily arbitrator fees. Compensation structures appear similar (ad hoc nomination and per hour fees). Two key differences are that (i) only investor claimants bring investment treaty cases whereas either party to a contract can claim in commercial arbitration; and (ii) investor claimants can frequently choose the forum or appointing authority after a dispute has arisen (under treaties giving investors a choice or through treaty shopping) whereas a single forum for commercial arbitration is generally chosen, prior to any dispute, by both parties to a contract. These and other important differences between commercial arbitration and investment arbitration may affect the incentives created, their impact and the degree of public interest in compensation arrangements. They may also produce higher public expectations about the need for institutional independence and impartiality of adjudicators and dispute settlement institutions.

A first annex to the paper reports on discussions about adjudicator compensation at the 2016 OECD Investment Treaty Conference. A second annex gathers some preliminary facts about adjudicator and dispute administrator compensation in investor-state arbitration and the ICS. It notes that there is limited public information and focuses on the direct impact on arbitrator compensation of certain decisions in individual cases. Increased arbitral fees arise from decisions rejecting government attempts to end claims early and can also result from decisions postponing jurisdictional or other potential claim-terminating objections until the merits; average amounts at issue are calculated based on available data. The fees for arbitration institutions, strong growth of their staff as a result of the expansion of ISDS, and apparent new entrants are also noted.

On the ICS in CETA, the basic initial compensation structure for the first instance tribunal involves a mix of salary paid by the treaty Parties and per day fees payable by litigants. A joint inter-governmental committee sets the initial monthly salary (retainer) paid for by the treaty Parties. Litigant fees are substantial, equivalent to the ICSID level (USD 3000/day); adjudicator decisions can accordingly affect the amount of future fees in a case. The compensation system for tribunal members can be transformed into a regular salary rather than the retainer and case fees model by the joint committee (which will also decide on the compensation regime for the appellate tribunal). The EU and Canada have proposed a plurilateral court structure applicable to a greater number of investment treaties and a consequently greater expected case flow that could provide more flexibility for compensation systems. 


\section{Introduction $^{2}$}

Compensation for adjudicators has become an important topic in current debates about investor-state dispute settlement (ISDS). It is widely recognised that the compensation structure in investor-state arbitration has helped achieve independence from host governments. But criticism is accumulating on other issues. The Economist has pointed to a direct pecuniary interest of investment arbitrators in case outcomes, stating that "[a]rbitrators are paid \$600-700 an hour, giving them little incentive to dismiss cases out of hand". ${ }^{3}$ Others see incentives to engage in lengthy and costly procedures, or an over-riding interest in future appointments due to the ad hoc nature of arbitral appointments. There have also been critiques of the possible multiple roles of the same person as arbitrator, legal counsel and expert, including concurrently in different investor-state cases.

Criticism of investor-state arbitration has often focused on perceived arbitral incentives to attract more business from investor claimants, but OECD Investment Roundtable discussions have noted possible incentives that could at times point the other way. Early Roundtable discussions on ISDS identified a possible arbitrator economic interest in preserving a lucrative ISDS industry. If there is significant public criticism of the scope of government liability or risk to the right to regulate in certain jurisdictions, this could for example create perceived incentives to narrowly construe often-flexible treaty provisions in particular cases to the detriment of certain investor claimants.

Sundaresh Menon, who was then the Attorney-General in Singapore and is now the Chief Justice, addressed the issue of economic incentives for ISDS arbitrators in a well-known 2012 speech. He underlined both the excessive nature of some criticism and the existence of issues for consideration:

Unbridled criticisms of how arbitrators are invariably profit-driven and biased, or that they always act strategically so as to be repeat players, are undoubtedly overstated. However, it is undeniable that the typical conditions that assure impartiality in the judicial sphere are lacking in arbitration. $^{4}$

New proposals in ISDS are also grappling with issues of adjudicator compensation and are facing evaluation and criticism of some initial approaches. The bilateral investment court system (ICS) included in CETA as signed in October 2016 provides for government appointment of adjudicators, but only partly

2 This paper has been discussed by governments participating in the OECD-hosted Freedom of Investment (FOI) Roundtable. The following economies are invited to participate in the Roundtable: Argentina, Australia, Austria, Belgium, Brazil, Bulgaria, Canada, Chile, People's Republic of China, Colombia, Costa Rica, Czech Republic, Denmark, Egypt, Estonia, Finland, France, Germany, Greece, Hungary, Iceland, India, Indonesia, Ireland, Israel, Italy, Japan, Jordan, Korea, Latvia, Lithuania, Luxembourg, Malaysia, Mexico, Morocco, Netherlands, New Zealand, Norway, Paraguay, Peru, Poland, Portugal, Romania, Russian Federation, Saudi Arabia, Singapore, Slovakia, Slovenia, South Africa, Spain, Sweden, Switzerland, Tunisia, Turkey, United Kingdom, United States and the European Union. Participation typically varies somewhat depending on the issues being discussed.

The paper does not necessarily reflect the views of the OECD or of the governments that participate in the FOI Roundtable, and it should not be construed as prejudging ongoing or future negotiations or disputes pertaining to investment treaties.

3 The Arbitration Game: Investor State Dispute Settlement, The Economist (11 Oct. 2014).

4 See Sundaresh Menon, International Arbitration: The Coming of a New Age for Asia (and Elsewhere), ICCA Congress 2012, Opening Plenary Session, $\S \S 39-40$. 
specifies the compensation arrangements, leaving key aspects for future decision or adjustment. The 2016 OECD Investment Treaty Conference saw discussion and criticism of the draft EU-Canada Comprehensive Economic and Trade Agreement (CETA) provisions on adjudicator compensation as well as of investorstate arbitration. Initial inter-governmental discussions about a possible multilateral dispute settlement system have also identified compensation arrangements for adjudicators and dispute settlement administrators, and their financing, as key issues for discussion with a range of views being expressed.

While adjudicator compensation has become part of the public and policy debate over ISDS, it has been subject to limited analysis to date. Compensation for adjudicators is generally considered in good institutional design for courts as a core issue for judicial independence and for attracting good judges. The Roundtable has pointed to the need for analysis of possible economic incentives in ISDS, but compensation systems for adjudicators have been rarely discussed as a policy issue amongst the ISDS policy community. Existing guidelines on conflicts of interest in arbitration prepared by the arbitration bar take ad hoc nomination and payment by the hour as a given. There is a growing focus on issues for individual arbitrators, but even in some recent papers addressing the ICS there is little or no attention to compensation systems.

This paper begins to examine issues of compensation of adjudicators and dispute settlement administrators in ISDS. It uses in part a comparative perspective based on approaches in domestic courts in advanced economies. ISDS has not often been subject to evaluation from this perspective. The Roundtable compared ISDS to the WTO and the European Court of Human Rights (ECtHR) in its initial work in 2012 and asked for views about some issues relating to conflicts of interest in the 2012 public consultation. ${ }^{5}$ But it did not ask questions about the differences between investor-state arbitration and well-established domestic courts, or about the ad hoc system of arbitrator nomination or per hour compensation.

Recently, the CETA Parties have emphasized that the ICS in CETA is "inspired by the principles of public judicial systems in the European Union and its Member States and Canada, as well as international courts such as the International Court of Justice and the European Court of Human Rights". ${ }^{6}$ Governments may of course have different views about the proper benchmarks for ISDS and the relevance of domestic court models depending on their treaty policy goals and context. However, regardless of whether governments use domestic courts in advanced economies as a benchmark, domestic courts are likely to be an important point of reference for the public in evaluating ISDS. Particularly where they are wellestablished, domestic courts are often known to the public at least in broad outlines. Arguments that an additional system is needed to oversee domestic courts in their role in controlling state power and providing remedies to private actors naturally invite comparisons between the domestic courts and the additional system.

Approaches to adjudicator compensation in domestic courts in advanced economies are accordingly examined here for analytical and comparative purposes. Future work will encompass international courts and tribunals. No view is expressed on the relevance of domestic courts as a benchmark for any particular government's treaty policy or treaty policy in general.

While the paper also reports on views about the impact of compensation systems on adjudicator behaviour, it similarly takes no position on the actual impact, if any, of economic interests in general or in particular cases; nor does it take a position on the relative importance, if any, of economic factors as opposed to other factors that may affect adjudicators. In preliminary Roundtable discussions, different

\footnotetext{
5 OECD, Public Consultation on Investor-State Dispute Settlement (2012).

6 Joint Interpretative Instrument on the Comprehensive Economic and Trade Agreement (CETA) between Canada and the European Union and its Member States (2016), § 6(f).
} 
governments and constituencies have expressed a range of views on whether economic incentives have affected ISDS adjudication in practice.

At the same time, it is important to note the importance of appearances in this context, which is widely recognised. As the European Court of Human Rights recently underlined, quoting Lord Hewart's well-known statement, "'justice must not only be done, it must also be seen to be done'. What is at stake is the confidence which the courts in a democratic society must inspire in the public ...". ${ }^{7}$ Of course, other factors besides compensation arrangements, such as the perceived qualifications of adjudicators, are also of importance in ensuring that justice is seen to be done. Some governments see a similar importance for party selection of adjudicators in this regard.

The remainder of the paper is organised as follows. The paper first provides historical context. Litigant fees payable to judges were widely used to compensate judges in colonial America, France and England in the $18^{\text {th }}$ century. By the early $19^{\text {th }}$ century, all three jurisdictions had abolished that system. Private payments to judges in individual cases were replaced by government salaries. Leading thinkers advocated for the changes and the reforms are seen as fundamental features of the courts. The second section of the paper considers the debate over the impact of compensation systems for adjudicators. It addresses historical and contemporary views on adjudicator incentives and behaviour with regard to jurisdiction, remedies, substantive law, and the length and cost of cases.

The third section briefly explores contemporary approaches to the compensation of judges in advanced economies including both institutional systems and additional rules on pecuniary interests of individual adjudicators. A fourth section explores the co-existence of courts with salaried judges and generally strong support for ad hoc fee-based commercial arbitration. A final section compares commercial arbitration and investment arbitration with regard to compensation arrangements and their potential impact, and public perceptions.

Annex 1 summarises the discussion relating to adjudicator compensation at the 2016 OECD Investment Treaty Conference. Annex 2 begins to gather some preliminary facts about adjudicator and dispute administrator compensation in investor-state arbitration and the ICS.

AK v. Liechtenstein, (Eur. Ct. H.R. 2015) § 67; R. v. Sussex Justices, Ex parte McCarthy ([1924] 1 KB 256 (Lord Hewart). 
This section considers the evolution of judicial compensation systems in colonial America and the United States, France and England in the late $18^{\text {th }}$ and early $19^{\text {th }}$ centuries. Remuneration of judges by private litigant fees, widespread in all three jurisdictions before 1776, was essentially abolished in all three between 1776 and 1825. Henceforth judges' remuneration took the form of comprehensive government salaries coupled with a prohibition against supplementing them. This section first outlines the nature of the earlier systems and criticism, and then describes the reforms.

\section{A. Eighteenth-century court systems and criticism of litigant fee-based compensation for judges}

\section{Courts and judges in eighteenth century England}

English courts and judges had several general characteristics in the eighteenth century. ${ }^{8}$ First, judges had significant security of tenure. A key advance occurred in the 1701 Act of Settlement when the English Parliament eliminated the power of the king to remove judges and established judicial tenure during good behaviour.

Second, judges received a substantial part of their income from fees paid by litigants. A law in 1760 provided for salaries for judges. ${ }^{9}$ But even after 1760 judges still continued to receive a substantial part of their incomes from fees paid by litigants. ${ }^{10}$ Many court officials were also dependent on fees.

Third, there were a number of courts in England and they were widely seen as being engaged in jurisdictional competition. As noted by Pfander and Dirk, in England, "a number of superior courts of law, equity, and admiralty competed for business and encroached on one another's jurisdiction". ${ }^{11}$ Holdsworth similarly finds that "[o]ne of the most inconvenient of all the anomalies which disfigured that English judicial system was the ill-defined and clashing jurisdictions of the various courts which administered the law". ${ }^{2}$

8 In colonial America, the courts were often based on English models and English institutions remained an important reference even after independence. While the discussion in this sub-section generally focuses on England, it is also relevant to the situation in colonial America and the United States in the 18th century and to policy debates and reforms there. See James E. Pfander, Judicial Compensation and the Definition of Judicial Power in the Early Republic, 107 Mich. L. Rev. 1 (2008) (hereinafter Pfander, Judicial Compensation).

Shimon Shetreet and Sophie Turenne, Judges on Trial: The Independence and Accountability of the English Judiciary (2d ed. 2013), § 2.8 (judicial salaries were first provided for in a 1760 Act). Earlier laws had provided for salaries but had not been made effective. Id.

Judges in colonial America were also frequently paid in fees. See Pfander, Judicial Compensation at p. 3 ("[a]t the time of the framing [of the US Constitution in the late eighteenth century], the judges of superior courts in England received two forms of compensation: a salary paid by the Crown and fees paid to the judges by the litigants themselves on a piecework basis. ... Fee-paid judges were also commonplace in colonial America ....").

11 James E. Pfander and Daniel D. Birk, Article III and the Scottish Judiciary, 124 Harv. L. Rev. 1613,1626 n.58 (2011).

1 William Holdsworth, A History of English Law 634 (7th ed. 1956) (describing issues of overlapping or uncertain jurisdiction and concurrent proceedings in different courts, including common law, equity and admiralty courts). 
Jurisdictional competition involved a number of features. One relatively visible aspect was the use of legal fictions - allegations of fact which judges would not allow the defendant to contest. ${ }^{13}$ Legal fictions allowed a much expanded range of claims in a particular court. For example, one legal fiction allowed the Court of Exchequer, tasked with collecting the King's revenue, to obtain jurisdiction over an ordinary private contract case. The plaintiff would claim that he was a debtor to the king and that the defendant's contract debt prevented the plaintiff from paying the king. A number of legal fictions involved false allegations. ${ }^{14}$ Competition was also seen by some as apparent over substantive law and remedies.

Fourth, there was limited appellate review in England and it was not unified. England "lacked any institutional analogue to the Court of Session, which acted as the only supreme civil court of Scotland and exercised supervisory review over all inferior courts of any jurisdiction." ${ }^{15}$ This has been seen as providing the courts with greater freedom to develop judge-made law:

Each court was free to develop its own law. The development of judgemade common law amply demonstrates this freedom. Courts defined and expanded their jurisdictions, developed new procedures, and introduced doctrinal innovations without asking permission from Parliament or any other authority. In fact, this is a defining characteristic of the common law system. Until the mid-nineteenth century, there was no system of appeals by which one set of courts could comprehensively review the decisions of others. This is important because a system of appellate review might have constrained intercourt competition by imposing uniformity. ${ }^{16}$

These characteristics of the courts, and in particular litigant fees, were to be increasingly debated and challenged.

\section{Criticism of litigant fees payable to judges and court officials in America and England}

Private fee-based compensation for judges attracted mounting criticism. In colonial America, "reliance on litigant fees to compensate judges had grown controversial during the eighteenth century". ${ }^{17}$ Pfander states that "[c]ritics understandably viewed [the] jurisdiction-expanding fictions as driven in part by the judges' selfish desire to increase their fee revenue."

The issue of judicial compensation was debated by leading thinkers as the draft US Constitution was prepared. In the well-known Federalist Papers from 1788, which promoted ratification of the draft Constitution, Alexander Hamilton emphasised the importance of financial considerations for judicial independence. He advocated for government payment of judicial remuneration and permanent appointments. In addition, because he considered that it could be generally observed that control of a

\footnotetext{
13 See J.H. Baker, The Law’s Two Bodies: Some Evidential Problems in English Legal History (2001), p. 41 ("The essence of the classic legal fiction is that proof of a certain fact was dispensed with by the simple expedient of denying any means of disputing it.")

Daniel Klerman, Jurisdictional Competition and the Evolution of the Common Law, 74 U. Chi. L. Rev. 1179 (2007).

James E. Pfander and Daniel D. Birk, Article III and the Scottish Judiciary, 124 Harv. L. Rev. 1613, 1626 n.58 (2011).

Klerman at p. 1187.

Pfander, Judicial Compensation at p. 4.

Id. at 10-11.
} 
person's income generates a power to influence him or her, a fixed provision for judicial income was vital to judicial independence:

Next to permanency in office, nothing can contribute more to the independence of the judges than a fixed provision for their support. The remark made in relation to the President is equally applicable here. In the general course of human nature, a power over a man's subsistence amounts to a power over his will. ${ }^{19}$

Hamilton thus advocated for the draft constitutional text providing that the judges of the United States "shall at stated times receive for their services a compensation which shall not be diminished during their continuance in office." Hamilton, who would become in 1789 the first Secretary of the Treasury, was aware of the fragile state of the federal budget and the possible need to adjust judicial salaries, but careful safeguards were needed. It does not appear that a fee-based system or private sector financing was suggested in the constitutional debates although further research would be required.

In England, the philosopher and law reform advocate Jeremy Bentham was a relentless and scathing critic of litigant fees payable to judges. In a major work later published as edited by John Stuart Mill, Bentham saw what he called the "fee-gathering system" as an incentive for complicated procedures that multiplied fees. ${ }^{20}$ Bentham saw the economic incentives to be so strong and shared between judges, lawyers and court officials that he referred to them as a collective business, "Judge and Co.".

Trained himself as a barrister (lawyer), Bentham focused in detail on what he saw as the many devices used by judges and court officials to promote their financial interests. ${ }^{21}$ For example, he deplored the use of legal fictions that encouraged mendacity from courts and litigants in order to generate fees: "Business-stealing, or jurisdiction-stealing falsehoods. King's Bench stole business from [the Court of] Common Pleas: Common Pleas stole it back again from King's Bench. Falsehood, avowed falsehood, was their common instrument." ${ }^{22}$ While he principally focused on the impact of fees on procedure and costs, he also briefly addressed the impact of fees on substantive law. ${ }^{23}$

19 The Federalist Papers: No. 79, Avalon Project, Yale Law School (emphasis omitted); see Roger J. Perlstadt, Article III, Judicial Power and the Federal Arbitration Act, 62 American University Law Review 201, 206 n.20 (2012) ("Alexander Hamilton defended the salary protections in Article III by suggesting that such protections help to eliminate bias ...").

Jeremy Bentham, Rationale for Judicial Evidence, Part 2, Book VIII, chs. II-XIX (1847); Jeremy Bentham, Scotch Reform (1808), in Bowring, Collected Works of Jeremy Bentham, vol. v.; Bentham's Draught for the Organization of Judicial Establishments, Compared with that of the National Assembly, with a Commentary on the Same (1790), in Jeremy Bentham, The Works of Jeremy Bentham, vol. 4 (Bowring ed. 1843).

The titles of some of the many chapters devoted to criticising the fee system in one of Bentham's major works on the judicial system reveal the fierce tenor of the criticism. See, e.g., Jeremy Bentham, Rationale for Judicial Evidence, Part 2, Book VIII, Chapter IV.: Particular Exemplifications Of The Vices Introduced By The Fee-Gathering Principle Into Technical Judicature.; Chapter V.: List Of The Devices Employed Under The Fee-Gathering System, For Promoting The Ends Of Established Judicature, At The Expense Of The Ends Of Justice; Chapter VI.: First Device-Exclusion Of The Parties From The Presence Of The Judge; Chapter XVIII.: Thirteenth Device-Fiction.; Chapter XIX.: Fourteenth Device-Entanglement Of Jurisdictions; Chapter XXIV.: Nineteenth Device-Laudation Of Jurisprudential Law.; Chapter XXV.: Habitual Contempt Shown By Judges To The Authority Of The Legislature; Chapter XXVIII.: Remedies Suggested For The Above Evils.

Id. Chapter XVIII.: Thirteenth Device-Fiction.

Id. Chapter XXVII.: Extension Of The Above Devices To Substantive Law, As Far As Applicable. 
Draper describes the vigour of Bentham's critique of the fee system as leading to delay, high costs and cases brought in bad faith:

The complexities and devices developed in the operation of civil justice in England had just one goal - to encourage the complexity of procedure and correspondingly to increase the fees of lawyers and judges. These 'feefed' professionals not only sought the gratuitous extension of causes, but also encouraged suitors of bad faith (mala fides) who were themselves seeking self-interested advantage or malicious aggression rather than justice. And most importantly, lawyers made themselves the only masters of the technicalities of the system and hence made themselves indispensable. The corruption he accused the profession of, especially judges, is not corruption in the sense of openly taking bribes; Bentham says he never knew of such a case. But rather that the technical system had been developed over a considerable period with Judge and Co. building-in delay and complexity at every step. He described civil courts as delay shops where 'delay is sold by the year as broadcloth is sold by the piece'. ${ }^{24}$

For Bentham, the problems were caused by governments that - through insufficient budgets and inexperience -- had failed to provide for judicial salaries and left the law to be developed by judges in their decisions. The result was constant conflicts between the interests of justice and the interests of judges (judicature):

The system of judicial procedure has been, in the main, the work, not of legislators but of judges: manufactured, chiefly in the form-not of real statutory law-but of jurisprudential law:-imaginary law, consisting of general inferences deduced from particular decisions. By primeval indigence, and inexperience on the part of the sovereign, judges left without salaries, but left with power to pay themselves by fees. Hence, as will be seen, a constant opposition between the ends of justice, and the ends (the original, and thence the actual ends) of judicature. ${ }^{25}$

For Bentham, it was normal and indeed proper for judges as for others to follow their own interests: in the same situation, "the conduct of any other part of the human species would have been the same". ${ }^{26}$ What was needed were better-designed institutions. For Bentham, the application of utilitarian principles required the elimination of fees for judges and court officials, and their replacement by salaries. As Draper describes, a "clear utilitarian principle could be established that a system of procedure must not provide the opportunity of benefit for the principal operators or managers of such a system. $" 27$

\section{Courts, judges and criticism in $18^{\text {th }}$ century France}

The principal courts in pre-revolutionary France were known as "parlements". The "parlements" were not parliaments in the modern sense, but rather primarily courts of law comprised of nobles as judges.

\footnotetext{
24 Anthony J. Draper, "Corruptions in the Administration of Justice": Bentham's Critique of Civil Procedure, 1806-1811, Journal of Bentham Studies, Vol. 7, No. 1, January 2004, p. 9 (footnotes omitted).

Jeremy Bentham, Scotch Reform (1808), in Bowring, Collected Works of Jeremy Bentham, vol. v.

Jeremy Bentham, Rationale for Judicial Evidence, Part 2, Book VIII, Chapter XXIX.: Apology For The Above Exposure.

Draper, p. 10.
} 
There were thirteen parlements; the most important one was in Paris. The parlements had broad jurisdiction over both appellate and important first instance matters. In addition to their role as courts, they also claimed and exercised some legislative and administrative responsibilities, increasingly in opposition to the king during the latter half of the eighteenth century.

Judges in the parlements and most of the legal profession purchased their offices from the king. As Doyle's study of 18th century venality in France outlines, "[r]ather than tax their richer subjects directly, French kings preferred to sell them privileged public offices, which further payments allowed them to sell or bequeath at will. By the eighteenth century there were 70,000 venal offices, comprising the entire judiciary, most of the legal profession, officers in the army, and a wide range of other professions - from financiers handling the king's revenues down to auctioneers and even wigmakers." ${ }^{28}$ Judges were remunerated in part by payments from litigants.

Doyle describes the broad criticism of the system:

The growth of venality in France was accompanied at every stage by public controversy. The most remarkable feature of all these discussions was the absence of any serious defence of the principle. It was raised only to be condemned. ... French critics of venality were most concerned about the sale of judicial office. They contended that it led to the sale of justice itself, to the appointment of incompetent or inappropriate magistrates, and to the exclusion of otherwise well-qualified candidates.... These arguments had become classic long before the end of the seventeenth century; and they would be endlessly rehearsed throughout the eighteenth. ${ }^{29}$

Voltaire in particular was a sharp critic of the parlements and of the venality of judicial offices. ${ }^{30}$ He wrote a "stinging parody of [the remonstrances of the parlements] which upheld fundamental laws, the fundamental laws of venal office .... the fundamental law which allows them to ruin the province and turns over to lawyers the property of widows and orphans". ${ }^{31}$ Nonetheless, venality was widely seen as unreformable due to the costs to indemnify the office holders.

Maupeou as Chancellor under Louis XV sought to fundamentally reorganise the courts in 1771 to eliminate the opposition of the parlements and provide free access to justice without private litigant payments to judges. While not central to the arguments, the high cost of justice was at issue and the benefits of free access to justice were emphasised. ${ }^{32}$ However, in the context of an absolute monarchy with

28 See William Doyle, Venality: The Sale of Offices in Eighteenth Century France (1999).

$29 \quad$ Doyle, p. 239.

See Voltaire, Oeuvres de Voltaire, vol. 22, Histoire du Parlement, pp. 365-67 (applauding the reforms to address popular opposition to venality of judicial offices, which had led to high legal costs payable by litigants to judges, by constituting new courts obliged to provide access to justice without charging fees payable to judges).

The venality of offices had some prominent defenders, including Montesquieu, who had been president of the Parlement of Bordeaux. But even defenders recognized that venality was widely condemned by public opinion. 'There is scarcely a man of good sense in France', noted Montesquieu, 'who does not cry out against venality of offices, and is not thereby scandalized.' See Doyle, p. 256.

Simon Schama, Citizens: A Chronicle of the French Revolution (1989), p. 110.

Doyle, p. 258 ("It was also hinted, though seldom spelt out, that the high cost of justice resulted from venality and that its abolition had opened the way to the free justice of which Maupeou also made so much.") 
no representative assembly, the parlements portrayed themselves as bulwarks against despotism. They benefitted at times in the pre-revolutionary period from significant intellectual and public support in their opposition to the king and to taxes. Although the new courts were supported by Voltaire and others, there was significant opposition and Louis XVI restored the parlements in $1774 .^{33}$

In 1788, faced with a financial crisis, Louis XVI agreed to a meeting of the Estates-General, which had not met since 1614. ${ }^{34}$ Public concerns were gathered in books (cahiers de doléances) in March-April 1789 and elections were held in preparation for the meeting of the Estates-General. The cahiers are considered to provide a uniquely valuable look at public attitudes of the time. ${ }^{35}$ A review of many of the cahiers found that $31 \%$ of them (and $47 \%$ of those from the third estate) attacked judicial venality. ${ }^{36}$

\section{B. Reform}

Litigant fees for judges and court officials, widespread in all three countries in 1770, were abolished in all three between 1776 and 1825. In the US and France, this occurred in connection with the establishment of fundamental principles at the core of modern government institutions. In England, the compensation changes occurred in piecemeal reforms that were a prelude to a long series of broader reforms to the courts and the judiciary leading up to the 1873 Judicature Acts, many inspired by Bentham. ${ }^{37}$

33 Doyle, p. 259 (noting that Voltaire was practically alone among the philosophes in supporting Maupeou, with others such as Diderot "criticising the chancellor's attack on the parlements as the sweeping away of the last obstacle to despotism; so that in the last analysis, whatever their defects, the stricken sovereign courts must be supported").

The Estates-General were assemblies elected by the three orders (or estates) in the ancien régime (the clergy, the nobles, and the people). The king would bring them together principally in order to raise new taxes. They were used regularly until the $16^{\text {th }}$ century before falling into disuse early in the $17^{\text {th }}$ century. See Dominique Joly, La Révolution française (2011), p. 12.

See François Furet et Denis Richet, La Révolution française (2001), pp. 69-72.

Daniel Gordon, Book review of William Doyle, Venality: The Sale of Offices in Eighteenth-Century France (1996) in The Journal of Modern History, vol. 71(3) (Sept. 1999) (citing Doyle at pp. 269, 273); see also Schama, p. 310. On the cahiers, see François Furet et Denis Richet, La Révolution française (2001), pp. 69-72.

Holdsworth, p. 633 ("Even before 1832 Bentham's teaching had begun to influence the legislature. After 1832 its influence was much increased; and law reform became the order of the day."). The influential $19^{\text {th }}$ English legal historian and scholar, A.V. Dicey, referred to the wave of reforms from 1825-1870 as Benthamism or Individualism. See J.H. Baker, English Legal History (4 ${ }^{\text {th }}$ ed. 2005), p. 216.

Bentham's ideas continue to have contemporary relevance including to additional debates over ISDS policy. See Vincent Rzepka, Transparency and the TTIP Negotiations: A Critique of the Common Sense, Kring vor internationale Betrekkingen KIB (10 Oct. 2016) (examining the TTIP transparency debate in the light of Bentham's views on transparency); Beverly McLachlin, Courts, Transparency and Public Confidence - To The Better Administration of Justice (2003) (speech by Canadian Chief Justice Beverly McLachlin discussing Bentham's views that "[w]here there is no publicity there is no justice. Publicity is the very soul of justice. It is the keenest spur to exertion and the surest of all guards against improbity. It keeps the judge himself while trying under trial."). See also Judith Resnik, The Democracy in Courts: Jeremy Bentham, 'Publicity', and the Privatization of Process, in No Foundations: An Interdisciplinary Journal of Law and Justice, No. 10 (2013) (noting that Bentham "was a major proponent of structuring encounters in many venues to provide the public with knowledge about and enable scrutiny of various actors and institutions - judges and courts, included. Open courts, codification of laws, and a free press were his methods for transferring authority to the public, forming a 'tribunal' whose opinions were to influence ruling powers"). 
In the United States, the issue of judicial compensation was explicitly addressed in the 1789 US Constitution. Article III -- in accordance with the text advocated by Hamilton in the Federalist Papers provides that federal judges "shall, at stated times, receive for their services, a compensation, which shall not be diminished during their continuance in office". The creation of a new Supreme Court in the United States as a federal appellate court gave rise to concerns about the budget and in particular the costs of the salaries of the new judges, especially in a difficult budgetary context following the revolutionary war. Even so, shortly after ratification of the Constitution, the US Congress adopted legislation in 1789 setting forth stated annual salary figures for Supreme Court and district judges payable quarterly. ${ }^{38}$ Congress fixed the salary of the Chief Justice $(\$ 4,000)$ at a figure above that of the Secretary of State $(\$ 3,500) .{ }^{39} \mathrm{In}$ addition to the salary and other costs, there was also the likelihood that the court would not be sufficiently occupied in the early years until cases on appeal reached the court. One solution was to require the judges initially to "ride circuit" -- to travel to sit on cases in the circuit courts located in different regions -- in addition to their duties on the court itself.

In France, the Estates-General had given rise to the National Assembly and the start of the French Revolution by June 1789. The principle of free public access to justice and the elimination of litigant fees payable to judges were proclaimed as part of the remarkable session of the National Assembly on 4 August 1789, described by the eminent historian François Furet as "the most famous date in French parliamentary history". ${ }^{40}$ The venality of public offices, including judicial offices, was eliminated; the judiciary, court administration and other state functions were opened to all citizens. These principles were reflected in the decree of 11 August 1789 which opened with the proclamation that the National Assembly had "entirely destroy[ed] the feudal regime". ${ }^{41}$ Furet has underlined the fundamental and lasting importance of the reforms carried out during the week of 4 August, which are among the founding texts of modern France. ${ }^{42}$

See Act of 23 Sept. 1789, ch. 18, 1 Stat. 72.

Pfander, Judicial Compensation at p. 30 ; Maeva Marcus, ed., Documentary History of the Supreme Court of the United States, 1789-1800, vol. 4 (Organizing the Federal Judiciary: Legislation and Commentaries) at pp. 19, 21 and n.7 ("In setting the pay for the justices of the Supreme Court and lower federal court judges, Congress needed to be fair yet at the same time frugal. As was evident from the debates over the ratification of the Constitution and the ongoing efforts to craft a judiciary bill, the expense of establishing the judicial branch was a major concern.”)

François Furet, Nuit du 4 août, in François Furet et Mona Ozouf, Dictionnaire critique de la révolution française (1988), p. 126.

See Decree of 11 August 1789, art. 1 ("L'Assemblée nationale détruit entièrement le régime féodal.") [“The National Assembly is destroying entirely the feudal regime.”] ; id. art. 7 ("La vénalité des offices de judicature et de municipalité est supprimée dès cet instant. La justice sera rendue gratuitement.") [“The venality of judicial and municipal offices is terminated with immediate effect. The public shall have free access to justice.'] The 11 August decree provided for compensation for judges whose ability to collect litigant fees and sell their offices had been eliminated, and for continued collection of fees until compensation was paid. This gave rise to lengthy disputes over valuation and payment. See Furet, p. 130.

Bentham applauded the French reforms in 1790, writing about the provision for free public access to justice and appropriate judicial salaries that "[s]o much good has seldom been proposed in so few words." Bentham's Draught for the Organization of Judicial Establishments, Compared with that of the National Assembly, with a Commentary on the Same (1790), in Jeremy Bentham, The Works of Jeremy Bentham, vol. 4 (Bowring ed. 1843), ch. I. tit. I, observation 4(d).

François Furet, Nuit du 4 août, in François Furet et Mona Ozouf, Dictionnaire critique de la révolution française (1988), p. 131 ("Le trait le plus important des décisions votées dans cette fameuse semaine d'août 1789 est leur caractère durable. La Révolution française a créé beaucoup d'institutions provisoires et légifère souvent pour le court terme ; mais les décrets du 4 au 11 août sont parmi les textes fondateurs de la France moderne. Ils détruisent de fond en comble la société aristocratique, et sa structures de dépendances 
The National Assembly was intent on providing for the dominance of the legislature and set forth the principle that the judicial courts are not competent to resolve matters involving the administration. ${ }^{43}$ This principle gave rise to the formation of the Conseil d'Etat in 1799 as a separate institution to address administrative matters and disputes, and ultimately to a dual system of civil and administrative courts (reflected in many civil law legal systems today). Members of the Conseil d'Etat received salaries and did not receive fees from litigants. Its powers to control administrative action were initially very limited but grew over time.

In England, the elimination of additional sources of income and in particular litigant fees took longer:

Developments since the Act of Settlement [in 1701] have further secured the independence of the judiciary. An Act of 1760 first established judicial salaries ... Only in the nineteenth century did [English] judges' remuneration take the form of comprehensive salaries coupled with a prohibition against supplementing it. Until then judicial salaries were supplemented by additional sources of income such as judicial fees, presents, profits arising out the sale of office, allowances for robes and loaves of sugar. The additional sources of income were eliminated in a very long, gradual evolution over three centuries. ${ }^{44}$

Parliament had a key role in the reform process, initially in gathering information. A 1798 report by the House of Commons Select Committee on Finance examined the issue of compensation of judges and court officials in detail. ${ }^{45}$ It set out the salary and fee income for different categories of judges. Fee income was generally substantial, especially for senior judges. ${ }^{46}$ Other Parliamentary reports on the condition of the courts followed. ${ }^{47}$

et de privilèges.') [The most important characteristic of the decisions adopted by vote during this famous week of August 1789 is their durability. The French Revolution created many provisional institutions and frequently legislated for the short term, but the decrees adopted during the week of 4-11 August are among the founding texts of modern France. They thoroughly destroyed aristocratic society and tis structures of dependence and privilege.']

As the Ministry of Justice website states, "one of the fundamental principles of the justice system in France is free access: judges are not remunerated by litigating parties but by the government." See La gratuité de la justice en France, Ministère de la Justice, France. ["L'un des grands principes de la justice en France est la gratuité : les magistrats ne sont pas rémunérés par les justiciables mais par l'État."]

Once a representative assembly came into being after the electoral process in 1789 , the parlements, composed solely of nobles, were largely sidelined. See Doyle, p. 278 ("Fearing the worst from the new order, their leaders largely spurned in the elections, the parlements kept quiet throughout the first half of 1789 ...") The parlements were disbanded by the National Assembly in 1790.

Law of 16-24 August 1790. See Ministère de la Justice (France), L'oeuvre révolutionnaire ; Les fondements de la justice actuelle.

Shimon Shetreet \& Sophie Turenne, Judges on trial: The Independence and Accountability of the English Judiciary (Cambridge 2d ed. 2013), pp. 30-31 (footnote omitted).

Twenty-Seventh Report from the Select Committee on Finance \&c.: Courts of Justice (1798) in Reports from Committees of the House of Commons, vol. XIII (1803), pp. 199 et seq. Id.; see also Klerman at 1188.

See Holdsworth, p. 635 ("During the first quarter of the nineteenth century the first steps towards reform were taken by the appointment of numerous commissions to enquire into the condition of the courts.") 
The 1798 Finance Committee report noted some initial parliamentary action to convert fees to salaries and expressed its support for that approach:

The judgment of Parliament on the propriety of giving fixed salaries to Judicial Offices, instead of any precarious emoluments, has been manifested by a law of the present reign, for regulating the Office of the Master of the Rolls and Your Committee think this to be a wise principle, and a salutary precedent. ${ }^{48}$

Statutes in 1799 and 1825 restricted royal judges to fixed salaries. ${ }^{49}$ Most judges were more than compensated for the loss of their fee and other non-salary income through increased salaries. Holdsworth notes that " $[\mathrm{w}]$ hen the income of the judges from fees was taken away in 1826 , their salaries were raised from [GBP] 2400 to [GBP] 5500". 50

Parliamentary oversight was also important to achieve implementation of the new rules on judicial compensation. Following US constitutional debates and the adoption of the Constitution in 1789, "Congress chose a salary-based compensation scheme, and took early steps to rule out fee payments to federal judges". ${ }^{51}$ In England, the House of Commons obtained detailed responses from individual judges in different courts about judicial salaries and fees which were recorded in Parliamentary Papers in $1832 .{ }^{52}$ Subsequent statutes also addressed court officials, providing for salaries and eliminating incomes that varied with fees. ${ }^{53}$

Twenty-Seventh Report from the Select Committee on Finance \&c.: Courts of Justice (1798) in Reports from Committees of the House of Commons, vol. XIII (1803), p. 202.

See Klerman at p. 1204 n.52 (citing Statute of 6 Geo IV, ch. 82 (1825); Statute of 6 Geo IV, ch. 83 (1825); and Statute of 39 Geo III, ch. 90 (1799)). See also Holdsworth, p. 262 (citing Statute of 6 Geo IV ch. 84 (1825)).

Holdsworth, p. 255.

Pfander, Judicial Compensation at pp. 24 et seq. (addressing some continued fee collection activities and Congressional action to eliminate them).

The responses of the individual judges appear in the 1832 Parliamentary Papers (vol. 35, 1832) (document 644) on Salaries of Judges and Fees.

See, e.g., An Act to abolish certain Offices in the Superior Courts of Common Law, and to make Provision for an more effective and uniform Establishment of Officers in those Courts, 1 Vict. 37 ch. 30 (1837).

In the United States, a long series of reforms in the $19^{\text {th }}$ century and early $20^{\text {th }}$ century saw the transformation of federal court clerks "from relatively autonomous officeholders who earned their livings from the fees that their offices could generate and who answered only to the judges who had appointed them, to salaried employees of a federal judicial bureaucracy ...." See I. Scott Messinger, Order in the Court: A History of Federal Court Clerks, Federal Judicial Center (2002), pp. 3, 9-45. The annual report of the Attorney General in 1912 noted the "wisdom of putting clerks on a salaried basis," and urged passage of legislation. Fees were finally replaced by salaries in 1919. Id. at pp. 41, 45. 


\section{The debate over the impact of judicial compensation systems}

In his Inquiry into the Nature and Causes of the Wealth of Nations, Adam Smith described a particular type of litigant fee system. It involved a fixed fee, paid in one instalment to a receiver, and distributed in a known proportion to judges after a decision is rendered in the proceedings ${ }^{54}$ Under those conditions, he considered that "there seems to be no more danger of corruption than where such fees are prohibited altogether" and that payment after a decision could encourage diligence. ${ }^{55}$ In contrast, he considered that mechanisms for progressive payments of litigant fees could cause judges to engage in unnecessary procedures to generate fees. ${ }^{56}$

Smith lauded the historical role of competition between the courts for fees in the earlier evolution of the English courts:

The fees of court seem originally to have been the principal support of the different courts of justice in England. Each court endeavoured to draw to itself as much business as it could, and was on that account, willing to take cognizance of many suits which were not originally intended to fall under its jurisdiction. The court of king's bench, instituted for the trial of criminal cases only, took cognizance of civil suits; the plaintiff pretending that the defendant, in not doing him justice, had been guilty of some trespass or misdemeanour. The court of exchequer, instituted for the levying of the king's revenue, and for enforcing of such only as were due to the king, took cognizance of all other contract debts; the plaintiff alleging that he could not pay the king, because the defendant would not pay him. In consequence of such fictions, it came in many cases, to depend altogether on the parties, before which court they would choose to have their case tried, and each court endeavoured, by superior dispatch and impartiality, to draw to itself as many causes as it could. The present admirable constitution of the courts of justice in England was, perhaps, originally in a great measure, formed by this emulation, which anciently took place between their respective judges; each judge endeavouring to give, in his own court, the speediest and most effectual remedy, which the law would admit, for every sort of injustice. ${ }^{57}$

Smith refers to the choice between competing courts depending on the "parties". Other scholars have underlined that where several courts are competing, the plaintiff (claimant) can often choose the court. Plaintiff choice can change the analysis.

$54 \quad$ Adam Smith, An Inquiry into the Nature and Causes of the Wealth of Nations, p. 301 ("where the fees of courts are precisely regulated and ascertained; where they are paid all at once, at a certain period of every process, into the hands of a cashier or receiver, to be by him distributed in certain known proportions among the different judges after the process is decided, and not till it is decided"). Id.

Smith saw that a stamp duty system involving progressive payments might tempt judges to multiply proceedings to increase revenue. Id. pp. 301-02 ("The judges, indeed, might in this case, be under temptation of multiplying unnecessarily the proceedings upon every cause, in order to increase, as much as possible, the produce of such stamp-duty.").

Id. p. 301 . 
William Landes and Richard Posner have argued that where competition is for plaintiffs who have the power to choose the court, a pro-plaintiff bias would be expected:

Imagine a system in which there are several courts, public or private, with overlapping jurisdictions, and the judges are paid out of litigant fees and therefore have a direct pecuniary interest in attracting business . . . [ [I]t might seem that competition would lead to an optimal set of substantive rules and procedural safeguards. But this is incorrect. The competition would be for plaintiffs, since it is the plaintiff who determines the choice among courts. The competing courts would offer not a set of rules to optimize dispute resolution but a set designed to favor plaintiffs regardless of efficiency. ${ }^{58}$

Landes and Posner noted that historical research revealed competition by the fee-based courts. However, they were unaware of evidence that it had produced the blatant plaintiff favouritism predicted by economic analysis and invited scholarly attention to this issue. ${ }^{59}$

Todd Zywicki has argued that competition between the courts in England gave judges incentives to provide efficient legal rules. ${ }^{60}$ He considers, however, that plaintiff choice was limited and that many courts needed to attract both plaintiffs and defendants. Where " $[\mathrm{m}]$ erchants could never predict which side of a dispute they would be on, ... they did not favor either pro-plaintiff or pro-defendant rules." ${ }^{, 61} \mathrm{He}$ also points to the importance of a choice of court before a dispute has arisen (ex ante) because the parties do not know at that time where they will stand in a future dispute:

Perhaps most crucial was the fact that, even though parties faced few formal constraints on where to bring their suits, this choice of jurisdiction was actually made ex ante rather than ex post most of the time. When the parties chose their jurisdiction, therefore, they did not know whether they would be more likely to be the plaintiff or the defendant in any subsequent litigation and so would be unlikely to prefer a biased court over an unbiased one. ${ }^{62}$

Daniel Klerman has treated the issue as an empirical problem and has used statistical analysis to examine the impact of fee compensation on legal doctrine in England. Contrary to Zywicki, he affirms the "crucial fact" that "[i]n nearly all cases, the plaintiff chose the court". ${ }^{63}$ His statistical analysis finds a proplaintiff bias during the period of compensation of judges through litigant fees:

$58 \quad$ William Landes \& Richard Posner, Adjudication as a Private Good, 8 J Legal Stud 235, 254 (1979); see also Jens Dammann \& Henry Hansmann, Globalizing Commercial Litigation, 94 Cornell L. Rev. 1, 6 n.10 (2008) ("Competition among courts is much more problematic in those cases in which the plaintiff can choose the forum unilaterally. In particular, this creates the risk that courts will compete by catering to plaintiffs rather than by improving the quality of their services.”); Vincy Fon and Francesco Parisi, Litigation and the Evolution of Legal Remedies, (2003) (predicting a pro-plaintiff bias where plaintiffs have choice of forum).

Landes \& Posner, p. 255.

Todd Zywicki, The Rise and Fall of Efficiency in the Common Law: A Supply-Side Analysis, 97 Northwestern Univ. L. Rev. 1551 (2003).

Id. at 1608 .

Id. at 1609.

Klerman at pp. 1184, 1186. 
Beginning in 1799, statutory reforms took fees away from the judges [in England]. By comparing judicial decisionmaking before and after passage of these statutes, it is possible to test empirically whether fee competition affected the development of the law. Statistical analysis of three newly created datasets provides results that are consistent with the hypothesis that competition resulted in a pro-plaintiff bias. ${ }^{64}$

Klerman also finds that the replacement of litigant fees with salaries resulted in less attention to plaintiff interests with greater development of pro-defendant doctrines "in the nineteenth century, after statutory reforms had taken fees away from the judges and thus dampened competition among courts". 6.

Pfander notes that "founding era debates [in eighteenth century America] took for granted the fact that the English superior courts had expanded their jurisdiction through the use of legal fictions. Fee-based compensation offered an obvious financial incentive for judges to indulge in such fictional docket expansion.". He considers that "[w]hether fees influenced substantive doctrine or not, it seems fairly obvious that fees may have encouraged judges to adopt a broad view of their own jurisdiction and their competence to grant expansive forms of relief." 66

In England, as noted, Bentham saw a system of "fee-gathering" courts and court officials as profoundly influenced by economic incentives including on issues of jurisdiction. Others have expressed similar views on the impact on jurisdiction. In a mid- $19^{\text {th }}$ century House of Lords case, Lord Campbell attributed an earlier anti-arbitration attitude in the courts to competition for fees under the earlier fee-based compensation system for judges:

My Lords, I know that there has been a very great inclination in the courts for a good many years to throw obstacles in the way of arbitration. Now, I wish to speak with great respect of my predecessors the judges; but I must just let your Lordships into the secret of that tendency. My Lords, there is no disguising the fact, that as formerly the emoluments of the judges depended mainly or almost entirely upon fees, and they had no fixed salary, there was great competition to get as much as possible of litigation into Westminster Hall, and a great scramble in Westminster Hall for the division of the spoil... Therefore, they said that the courts ought not to be ousted of their jurisdiction, and that [arbitration] was contrary to the policy of the law. ${ }^{67}$

Pfander has suggested that because fee-paid judges were widely understood to have a financial interest in expanding their jurisdiction, the decision to place federal judges on salary in Article III "may have provided subtle institutional support for the notion that federal courts were to be courts of limited

\footnotetext{
$64 \quad$ Klerman at p. 1182.

65 Id. at 1182.

Pfander, Judicial Compensation at pp. 4-5, 11.

Scott v Avery (1856) 5 HLC 811, 10 ER 1121, quoted in Raguz v. Sullivan, [2000] NSWCA 240 (New South Wales Court of Appeal 2000). The Raguz court considered that "[ $\mathrm{t}]$ he common law's opposition to arbitration also stemmed from less worthy perspectives. The desire for exclusive control will often have an economic motive not far below the surface. With arbitration, it was not just the barristers whose livelihood was threatened."

The judges in Raguz also noted that Lord Campbell's reference to the judges' economic interest must have "caused quite a stir" and that it was replaced in certain later published reports of the House of Lords case.
} 
jurisdiction". ${ }^{68}$ His review of the early decisions by US federal courts suggests a narrow judicial approach to the scope of jurisdiction following the adoption of salaries: "to a striking degree, early jurisdictional controversies tended to flow from the refusal of the judges to take on new assignments". ${ }^{69}$

For current policy makers, the view among many leading thinkers that compensation structures affect adjudication is likely more important than the debate over the historical impact. ${ }^{70}$ These considerations are relevant for the legitimacy and public confidence in dispute settlement systems that may be likely to be seen to create particular incentives. Information about and explanation of policies with regard to the incentives could help to address public concerns.

\section{Contemporary approaches to compensation for judges}

Judges in courts in advanced economies appear to be rarely subject to challenge in public debate or to disqualification on the basis that they are structurally subject to financial incentives affecting outcomes. As a matter of institutional design, permanent appointments and salaries are generally seen as important elements in achieving public confidence on these issues. Beyond institutional matters, domestic legal systems also apply rules to the individual pecuniary interests of particular judges. Like the provision of salaries, these rules are generally seen as contributing to judicial independence and public confidence in the justice system. These institutional and more individual aspects are addressed in turn.

\section{A. Stable government-paid salaries and other institutional arrangements}

This sub-section provides a brief and preliminary overview of some institutional principles relating to compensation of judges that appear to be of general or broad application in courts in advanced economies. The focus is principally on senior courts that decide the most important cases and appeals as most relevant to possible standards for or comparison with ISDS. The analysis is preliminary and limited to a relatively small number of jurisdictions. There are important differences between many civil law systems where young law school graduates join the judicial civil service shortly after completion of their legal educations and common law systems, where judges are appointed in mid-career, often from the private bar. The number of judges also varies significantly. The analysis can be corrected, qualified and completed by additional work and by information from governments.

Today salaries for judges are a well-established principle in court systems in advanced economies. The potential of economic leverage over judges is widely recognised as an issue requiring careful attention in the design of the courts. ${ }^{71}$ It is seen as of fundamental importance to the independence and integrity of the judiciary. Shetreet and Turenne describe the current approach in England:

68 See Pfander, Judicial Compensation at pp. 5-6.

69

70

$$
\text { Id. }
$$

Klerman notes that some legal historians have rejected the view that judges were affected by competition or fee income. See Klerman at 1185 (citing A.W.B. Simpson, A History of the Common Law of Contract: The Rise of the Action of Assumpsit 292-95 (Oxford 1975)).

See, e.g., Richard Posner, What do Judges Maximise? The Same Thing Everyone Else Does, Supreme Court Economic Review, vol. 3. (1993), pp. 1-41, at p. 2 ("almost the whole thrust of the rules governing 
Underlying the whole question of judicial remuneration, however, is that of the independence and integrity of the judiciary and the consequent need to secure the independence of judges from not only political but also financial pressure and entanglements. Judicial independence thus requires that judicial remuneration should be guaranteed by law. [In England,] [j]udges are paid out of the Consolidated Fund which means that their salaries are immune from challenge by backbenchers and cannot be reduced other than by statute itself. They may be increased by administrative action. Safeguards must be in place if they are to be decreased. $^{72}$

Second, remuneration to judges in the senior courts comes solely from the government. Litigants do not pay particular judges or officials. Fees for litigants to access the courts are paid to the government or the court. Remuneration of judges and court officials does not depend on the amount of court fees collected from litigants. ${ }^{73}$ The principle of government financing of the courts, dating from 1789, remains at the core of the French system of justice. It does not appear that there have been any suggestions for a return to litigant fee-based systems of judicial remuneration in France or elsewhere. ${ }^{74}$

Once judges are paid solely by the government rather than by private parties, concerns about institutional economic influence become more focused. The issue becomes possible influence by other parts of the government, such as executive or legislative bodies. Government salaries mean that private

compensation and other terms and conditions of judicial employment is to divorce judicial action from incentives -- to take away the carrots and sticks, the different benefits and costs associated with different behaviors, that determine human action in an economic mode").

The UK is distinctive because, in addition to its full-time salaried professional judges, it relies significantly on members of the legal profession acting as part-time judges, particularly in the lower tiers of the judiciary. Id. $\S \S 3.2,4.18$. Part-time judges are used to fill a need and often work on an as needed basis. The posts can also serve as a training ground for future full-time judges. Some part-time judges are salaried while most are paid on a per day basis. There are no litigant fees payable to part-time judges.

In the United States, while the federal court judiciary has tenure and salary protections in accordance with Article III, lower tier adjudicators such as administrative agencies, bankruptcy courts, courts-martial, and federal magistrate judges all exercise judicial power over Article III disputes without tenure and salary protections. See Roger J. Perlstadt, Article III Judicial Power and the Federal Arbitration Act, 62 Am. U.L. Rev. 201, 204 (2012). Both courts and commentators have explored the contours of Article III and discussed when and how non-Article III tribunals may resolve Article III disputes.

Private arbitration, an important type of adjudication of Article III disputes by non-Article III bodies, has received much greater analysis and debate in recent years, and has been the subject of a number of recent cases. See id; Peter B. Rutledge, Arbitration and Article III, 61 Vand. L. Rev. 1189 (2008). (See section IV. below.)

See Posner, supra at p. 5 ("Another reason there is no carrot is that a judge is, of course, forbidden to accept bribes from litigants, to pocket filing fees or other fees levied on litigants, or to collect royalties from people who cite his opinions. He gets a fixed salary, period.").

See Eric Posner, G. Mitu Gulati \& Stephen J. Choi, "Are Judges Overpaid?: A Skeptical Response to the Judicial Salary Debate" (John M. Olin Program in Law and Economics Working Paper No. 376, 2007), p. 4 ("No one, however, advocates making a judge's wages turn on the quality or quantity of her judicial output, which in any event would be constitutionally dubious.") (footnote omitted). 
economic influence over judges as an institutional matter is largely excluded. Private sector influence through economic interests may be an issue for individual judges with particular pecuniary interests. ${ }^{75}$

Third, judicial salaries benefit from significant stability. Decreases in judicial remuneration are rare although they can occur in the context of general measures applicable across the public service. Protections similar to those in Article III of the US Constitution have been incorporated into some other constitutions. $^{76}$ Shetreet and Turenne note that judicial salaries have not been decreased without the consent of the judiciary in England since $1832 .{ }^{77}$ They also describe how a range of court systems in advanced economies seek to reconcile the need to set and occasionally adjust judicial salaries with judicial independence. Some jurisdictions like Canada and the UK have instituted independent judicial review commissions or review bodies that provide advice to the government on judicial salaries. ${ }^{78}$

Fourth, amounts paid to judges in salaries and expenses are often disclosed to the public. The initial US statute in 1789 disclosed the salaries of the new federal judges and current information is easily available. In Canada, the Judges Act sets out the salaries of judges. France makes available tables listing judicial salaries. ${ }^{79}$

Fifth, judicial salaries appear to vary significantly between court systems in advanced economies although comparisons are difficult. Comparative information for European countries is gathered by the Council of Europe. Recent reports indicate the following salaries for Supreme Court judges in France (116 $751 €$ ), Germany (110 $011 €)$, UK- England and Wales ( $€$ 256, 206 - 2012 data); US USD 263,300. ${ }^{80}$ Shetreet and Turenne set out some of the relevant policy considerations, to some degree focused on the common law mid-career recruitment model. ${ }^{81}$ There is debate and concern in a number of jurisdictions about whether current levels of judicial compensation are sufficient to attract high-quality judges. The incomes of the highest paid lawyers have risen steeply in some jurisdictions. Judicial salaries have lagged behind. Debates have occurred in particular in common law jurisdictions. ${ }^{82}$ Debates over compensation can be bound up with other issues such as a perceived lack of diversity of the pool of judges.

75 Corruption of judges raises issues of private influence but is not addressed here. Adequate salaries are generally seen as important in the fight against judicial corruption.

In some situations, judges may have work-related economic interests that extend beyond their salaries and remuneration, such as where they need to finance election campaigns. The issue is not addressed here.

See, e.g., Constitution of Japan, arts. 79-80 (providing that Supreme Court and lower court judges "shall receive, at regular stated intervals, adequate compensation which shall not be decreased during their terms of office").

Shetreet \& Turenne, $\S 4.44$.

Id. $§ 4.43$;

See United States Courts, Judicial Compensation; Canada, Judges Act, R.S.C.. 1985 §§ 9-24. The tables of judicial salaries in France are available for example on the website of the Ecole nationale de la magistrature (judicial courts) or in a publication by the Conseil d'Etat (administrative courts).

Council of Europe, European Commission for the Efficiency of Justice, European Judicial Systems: Efficiency and Quality of Justice (2016 - 2014 data), p.110; United States Courts, Judicial Compensation.

Shetreet and Turenne $\S 4.41$.

See, e.g., Owen Boycott, UK judges disillusioned after drop in pay and conditions, survey finds, The Guardian (11 Feb. 2015). Senior US judges have expressed serious concerns. Chief Justice John Roberts, 2006 Year-End Report on the Federal Judiciary, (1 Jan. 2007); Hearing on Judicial Security and Independence Before the S. Comm. on the Judiciary, 109th Cong. (2007), (statement of Anthony M. Kennedy, Associate Justice of the United States Supreme Court). 
Six, there are generally significant limits on remuneration from other sources and outside activities although practices may vary and more research is required. A number of jurisdictions place strict limits on the outside activities of judges and their access to additional income, perhaps related in some cases to historical practices on judicial fees. In England, "while holding office, judges may not, by convention, take up any other engagement for further remuneration." 83 Accordingly, sitting judges cannot serve as arbitrators. A Delaware program to allow state Chancery Court judges to arbitrate disputes confidentially was found unconstitutional by a federal appellate court as contrary to the public right of access to the courts. $^{84}$

Seventh, judges are appointed for life or for significant fixed terms with a possibility of reappointment. The three jurisdictions addressed in the historical section above all appoint judges for life. Some other countries use term appointments. Re-appointment procedures following term appointments can be seen as raising issues of influence and they have been addressed in some court decisions. ${ }^{85}$

\section{B. Beyond providing for stable salaries and other institutional arrangements, governments apply additional rules to exclude the influence of pecuniary interests.}

In addressing issues of bias, courts in many domestic law systems focus primarily on apparent bias. ${ }^{86}$ While actual bias is of course seen as a problem, most decisions are framed as issues of apparent bias. As noted above, attention to appearances is widely seen as necessary to ensure public confidence in the administration of justice. ${ }^{87}$ It is also often difficult and delicate to evaluate actual bias in adjudication direct questioning of adjudicators about their state of mind is generally excluded in part because it is not seen as likely to produce persuasive evidence. Decisions about the actual state of mind of adjudicators are also not seen as likely to strengthen public confidence in the adjudication system. A finding of apparent bias does not require a finding about the actual state of mind of the adjudicator.

The standard for decisions about apparent bias is often described as incorporating an objective standard. It is not a subjective inquiry into the mind of the particular judge. It is rather an inquiry into whether an outside observer would consider that the facts are such as would likely affect the judge's decision-making. In the field of apparent bias, perceptions are key.

Some jurisdictions establish especially strict rules for pecuniary interests. In the UK, it is not necessary even to consider whether there is apparent bias when money is at issue. Once a pecuniary interest is established, a judge is disqualified. This rule, often termed as one of "automatic

$\begin{array}{ll}83 & \text { Shetreet \& Turenne, } \S 4.45 . \\ 84 & \text { Delaware Coalition for Open Government, Inc. v. Strine, } 733 \text { F.3d 510, } 512 \text { (3d Cir. 2013). }\end{array}$

See A.K. v Liechtenstein, (E. Ct. HR 2015) $\S \S 32,74,76$ ("As regards the objective test, the Court finds that none of the numerous grounds as such on which the applicant challenged the five judges of the Constitutional Court for bias were sufficient to raise legitimate and objectively justified doubts as to the judges' impartiality. ... [T] he judges' independence was not compromised by their term of office of five years", from which they could be re-elected).

This section primarily addresses common law jurisdictions at present. Initial research into civil law jurisdictions in some advanced economies suggests that issues of individual pecuniary interest may arise less frequently in cases, perhaps because a career judiciary has less contact with the business world. Research is continuing in this area.

See, e.g., AK v. Liechtenstein (Eur. Ct. H.R. 2015) § 67; R. v. Sussex Justices, Ex parte McCarthy ([1924] 1 KB 256 (Lord Hewart). 
disqualification", is generally traced to the House of Lords decision in Dimes v. Proprietors of Grand Junction Canal. ${ }^{88}$ A leading treatise summarises the applicable law:

The courts have long insisted that any pecuniary interest disqualified the decision-maker be he high or low. Thus, in Dimes the House of Lords reversed a decision made by the Lord Chancellor, Lord Cottenham, when the latter had affirmed decrees by the Vice-Chancellor in relation to a company in which the Lord Chancellor held some shares. There was no imputation of any actual bias made against Lord Cottenham, but it was held that the principle that no man can be a judge in his own cause must be sacred. The courts have consistently held that if there was a pecuniary interest it was not necessary to consider reasonable suspicion or real likelihood of bias. It is therefore important to establish what will constitute a pecuniary interest.

Blackburn J. held that any pecuniary interest, however small, will be sufficient. Some qualification is however required to this statement. If the pecuniary interest is not personal to the decision-maker then the matter will fall to be considered as a challenge on the grounds of favour. Moreover, if the alleged pecuniary interest is extremely remote, or based on contingencies that are unlikely to materialise, then the matter will similarly be treated as a challenge on the grounds of favour. Subject to these qualifications, the prohibition of pecuniary interest seems to be absolute and is not further qualified by any requirement that the interest be substantial. $^{89}$

Commonwealth courts have taken different approaches to the automatic disqualification rule, but appear to agree that in practice pecuniary interests will be carefully monitored. The Australian High Court rejected the automatic disqualification rule in favour of a unified approach to different types of bias in Ebner v. Official Trustee in Bankruptcy. However, the court pointed out that "economic conflicts of interest are likely to be of particular significance" and suggested that in practice little would change. ${ }^{90}$ Judge Kirby dissented and outlined the rationale for a bright line rule. The New Zealand Court of Appeal noted the decision in Ebner, but left the automatic disqualification rule in place in Muir v Commissioner of Inland Revenue, finding that it was not required to decide the issue. ${ }^{91}$ It noted that "[i]f a judge has a pecuniary interest of anything more than the most minimal character, it is hard to see how the reasonable observer would not see this to be "bias"'.

Paul Craig, Administrative Law ( $7^{\text {th }}$ ed. 2012) $§ 14-002$. The per se rule automatically disqualifying a judge for any pecuniary interest that is more than de minimis, without further inquiry, contrasts with the approach to other types of bias. For other kinds of personal interests, there is no automatic disqualification based on the existence of the interest. Rather, disqualification of the decision-maker generally occurs if the court goes on to find that "the interest gave rise to a reasonable suspicion or real danger of bias". Id. at 14-003.

See Ebner v. Official Trustee in Bankruptcy, [2001] 205 CLR 337 (High Ct. Aust.) ("we accept that, in the practical application of the general test to be applied in cases of apprehended bias, economic conflicts of interest are likely to be of particular significance, and that, allowing for the imprecision of the concept, the circumstance that a judge has a not insubstantial, direct, pecuniary or proprietary interest in the outcome of litigation will ordinarily result in disqualification.”). See generally Grant Hammond, Judicial Recusal: Principles, Process and Problems (2009). 
In the US, the case of Tumey v. Ohio established the proposition that, under the US constitutional guarantee of due process, pecuniary interests are subject to a stricter rule than other forms of bias. ${ }^{92}$ The Supreme Court has stated that a court considering issues of pecuniary interest is "not required to decide whether in fact [the justice] was influenced"; the proper constitutional inquiry is whether sitting on the case "would offer a possible temptation to the average . . . judge to . . . lead him not to hold the balance nice, clear and true". ${ }^{93}$ A 1974 federal statute establishes additional rules on financial and other interests and a further 1989 statute increased judicial salaries and places strict limits on outside earned income. ${ }^{94}$

Domestic courts have also considered how the availability of additional or other proceedings, such as appeals or challenge procedures, may affect the evaluation of pecuniary interests in an initial adjudication. Some US courts have suggested that impartial judicial review or impartial appellate proceedings may not be sufficient to cure a defective initial process. ${ }^{95}$ The UK courts have also addressed this issue, with some indication that the nature of second-tier review may be an important factor. ${ }^{96}$ US courts have also rejected the suggestion that the availability of disqualification of biased judges in particular cases is sufficient to address a conflict of interest arising from an institutional structure for adjudicator compensation. ${ }^{97}$

Aetna Life Ins. Co. v. Lavoie, 475 U.S. 813, 825 (1986); see also Withrow v. Larkin, 421 U.S. 35, 47 (1975) (in case involving adjudication by an administrative tribunal over a licensing issue, court finds that situation where "adjudicator has a pecuniary interest in the outcome" is one where "experience teaches that the probability of actual bias is too high to be constitutionally tolerable"); Gibson v. Berryhill, 411 U.S. 564,579 (1973) (" $[\mathrm{i}] \mathrm{t}$ is sufficiently clear from our cases that those with a substantial pecuniary interest in legal proceedings should not adjudicate these disputes").

See 28 U.S.C. $§ 455$; Ethics Reform Act of 1989, Pub. L. No. 101-194, 103 Stat. 1716 (1989); see also Jonathan L. Entin, Getting What You Pay For: Judicial Compensation and Judicial Independence, (2011), Faculty Publication; Paper 84.

See Ward v. Village of Monroeville, 409 U.S. 57, 61-62 (1972) ("Nor ... may the State's ... procedure be deemed constitutionally acceptable simply because the State eventually offers a defendant an impartial adjudication. Petitioner is entitled to a neutral and detached judge in the first instance."); Gibson v Berryhill, 411 U.S. 564, 577 (1973) (biased administrative proceeding could halted immediately even though judicial review, de novo or otherwise, would be available at the conclusion of the administrative proceedings, citing Ward).

See Leary v. National Union of Vehicle Builders, [1970] 2 All ER 713 (Chancery Court); Calvin v. Carr, [1980] AC 574 (Privy Council).

See Ward v. Village of Monroeville, 409 U.S. 57, 61 (1975) (in case finding breach of due process based on compensation structure for adjudicators under a legislative scheme, availability of separate procedure for disqualification of individual adjudicators was irrelevant because it was apparently designed only for objection to a particular adjudicator "in a specific case where the circumstances ... might warrant a finding of prejudice in that case" and was not suited for a challenge to a compensation regime) (emphasis in original). 


\section{The co-existence of courts and commercial arbitration with different compensation structures}

This section addresses the co-existence in many legal systems in advanced economies of wellestablished principles for the compensation of permanent judges with salaries together with public support for ad hoc commercial arbitration based on a different fee-based compensation model.

An initial aspect facilitating co-existence may have been very limited exposure of public entities and governments to commercial arbitration in at least some advanced economies until relatively recently. This may have affected the level of public interest in the differing approaches to adjudicator compensation in commercial arbitration and domestic courts. In some jurisdictions, arbitration was primarily an affair between private parties or between private parties and foreign state entities. Policy issues could arise at times about issues like the scope of issues that private parties could subject to commercial arbitration or the scope of review of awards, but the public purse was not at issue in commercial arbitration. Public entities litigated and public law issues were addressed primarily in the courts.

For example, in a 1995 case, the first to address the issue of the constitutionality of the US government submitting to commercial arbitration, a US court noted that for 150 years until 1994, the US Department of Justice took the position that the US Constitution prohibited the United States from submitting to binding commercial arbitration. ${ }^{98}$ In France, the Conseil d'Etat has generally interpreted art. 2060 Code Civil to establish significant limits on agreement to arbitration by public entities and reviews arbitration awards on public law issues. ${ }^{99}$ A recent survey of arbitration and the public interest under English law also notes that arbitration in that jurisdiction has primarily been conceived of as a private matter. ${ }^{100}$ Government use of commercial arbitration in advanced economies has expanded in recent years, generating controversy at times about issues such as expense or lack of transparency, but over the long period since the establishment of the basic principles for judicial compensation, it appears to have been limited. ${ }^{101}$

In Tenaska Washington Partners II, L.P. v. United States, 34 Fed. Cl. 434 (1995), the US government sought to compel compliance with a commercial arbitration clause in a contract between a federal agency and a private party. The court noted the long-standing government view that the government was not permitted to submit to such arbitration under the Constitution. Id. at 438 ("For over 150 years of legal practice, extending to modern venues, the United States, acting through the Department of Justice, positioned that the Constitution bars the United States from submitting to binding arbitration by an independent arbitrator.") The court noted, however, that the government had changed its position in 1994. It was now arguing that the government could submit to commercial arbitration in some cases. The court was convinced to apply the new government position to the contract arbitration context by a lengthy Department of Justice analysis which set forth the view that government agreement to binding arbitration would be constitutionally permissible under certain conditions.

For a statement of the current principles, see Conseil d'Etat (Ass.), No. 388806 (9 Nov. 2016); Tribunal des conflits, No. C4043 (11 April 2016). See also Cour de Cassation, Syndicat mixte des Aéroports de Charente v. Ryanair, No. 797 (8 July 2015) (13-25.846).

Stavros Brekoulakis and Margaret Delaney, Public-Private Arbitration and the Public Interest under English Law, (working version, 2016), pp. 32-33 ("arbitration in England has traditionally been embedded in private law and developed as an exclusively private mode of dispute resolution").

Where government entities can agree to arbitration, there appear to be increasing issues about the interaction of public law principles such as transparency with commercial arbitration approaches. In Brazil, amendments in 2015 to the arbitration law resolve previous uncertainties and expressly allow public entities to use commercial arbitration in certain cases. The law provides that arbitration involving public 
The co-existence of the two different systems has also been facilitated by findings that a party agreeing to commercial arbitration has waived its claim to object to certain pecuniary interests in adjudicators. A New Zealand court has noted that this exception to the automatic exclusion rule was established by the House of Lords in a case shortly after it had set forth the strict rule on pecuniary interests in Dimes:

It appears clear, therefore, that, once the pecuniary interest is established, the question whether there was in fact bias or a likelihood of bias, or whether a reasonable man would reckon bias to exist, does not require consideration. ...

It appears to me, however, that there are important exceptions to the common law notion of automatic disqualification ... [An] exception exists where by consent inter partes or by binding agreement (as for example appointing an arbitrator in a building contract ...) a person has assented to his rights being entrusted to someone who may have a financial or other interest in the result, or a bias. In such a case there can be no complaint as to the Judge acting in his own cause, but only of his failure to act judicially and impartially when he actually comes to perform his judicial functions. ${ }^{102}$

In the United States, rights to access to an Article III judge, who has life tenure and a salary, have been found to be waived where a party has agreed to arbitration. ${ }^{103}$ Waiver can be relevant to disputing parties' rights with regard to adjudicator compensation arrangements, but there can also be broader policy considerations in domestic law which may not be waivable by litigants. ${ }^{104}$

A third aspect that may be relevant to co-existence of differing compensation systems is that in commercial arbitration, both parties agree to waive their access to the courts, but both parties also agree to subject themselves to claims in arbitration. This issue is further addressed in the next section.

entities must always remain public. See Brekoulakis and Delaney, pp. 19-20 (citing Law No. 13,129 of 26 May 2015).

Jeffs v. New Zealand Dairy Production and Marketing Board, 1965 NZLR 522 (Sup. Ct. 1964) (citing Ranger v. Great Western Railway Co. (1854) 5 H.L.C. 72, 88, and noting it distinguished Dimes v. Grand Junction Canal Company, (1852) 3 HL Cas 759).

See, e.g., Geldermann, Inc. v. Commodity Futures Trading Comm., 836 F.2d 310, 316 (7 $7^{\text {th }}$ Cir. 1987) (compelling arbitration based on a waiver theory; "Article III's guarantee of an impartial and independent federal adjudication is subject to waiver, just as are other personal constitutional rights that dictate procedures by which civil and criminal matters must be tried.").

As Paul Craig notes, "[ $\mathrm{t}]$ he premise behind the ability to waive is that it is only the individual who is concerned, and thus if that person 'chooses' to ignore the fact that the adjudicator is an interested party then so much the worse for the applicant. However, there may well be a wider interest at issue, in that it may be contrary to the public interest for decisions to be made where there may be a likelihood of favour to another influencing the determination.” Craig, § 14-011. 


\section{Commercial arbitration and investment treaty dispute settlement}

This section considers some similarities and differences between commercial arbitration and investment arbitration relating to compensation arrangements and their potential impact, and public perceptions. Commercial arbitration is similar to investment arbitration in terms of compensation arrangements for adjudicators and administrative bodies. Ad hoc appointments and hourly fees for adjudicators are similar, and fees are also typically payable by the disputing parties to administering bodies in both systems.

Relatively little information is made publicly available about compensation under either system, with the notable exception of the ICSID USD 3000 cap on daily arbitrator fees. Arbitration institutions generally make their billing policies available for both types of cases, but not the amounts billed. However, while the compensation structures are similar, important differences may exist that may affect the incentives created, their impact and the degree of public interest in the issues.

A first key difference is the scope of the claimant's power to choose the forum after the dispute has arisen. As noted above, commentators have seen significant differences in the impact of competition between courts depending on the degree of plaintiff choice of courts. Contracts calling for commercial arbitration are generally drafted pre-dispute. They also generally provide for a single appointing authority and arbitration institution chosen at that time. In contrast, investment treaties typically provide claimants with considerable post-dispute choice over appointing authorities and dispute settlement administrators. Most treaties provide claimants with post-dispute choices of arbitration rules and consequently of appointing authorities. The broad scope for treaty shopping, notably through the current wide-spread acceptance in ISDS of indirect shareholder claims for reflective loss, reinforces the scope of claimant postdispute choice.

Second, in commercial arbitration, either contract party can be a claimant. Generally, neither side knows beforehand, at the time they negotiate a contract with an arbitration clause providing for an appointing authority, who will be the claimant. Without this knowledge, it is generally difficult for the parties to predict who may be seeking broad interpretations of jurisdiction or other claimant-favourable interpretations. ${ }^{105}$ Well-informed parties and their counsel are aware of the widely-seen economic incentive to broadly interpret jurisdiction under a fee-based system. But at the time they negotiate the contract and choose their normally unique appointing authority, they generally do not know what their position on jurisdiction will be. ${ }^{106}$

In contrast, investment treaty cases are brought only by investors. The investor will always be the party seeking broad findings on jurisdiction. It will also generally seek broad interpretations of treaty protection and available remedies. This is known to parties and arbitration market participants at all times. This includes the time, post-dispute, when the investor chooses an appointing authority.

105 Jurisdiction is used here for convenience. Similar issues with regard to direct pecuniary interests appear to arise for other issues that can be outcome-determinative early in a case or sharply limit the scope of a case, such as early proceedings to terminate a case for lack of a legal basis.

106 Parties to commercial arbitration do likely know their position at the time they choose their co-arbitrator. That occurs after the dispute has arisen. But the appointing authority has already been jointly selected at an earlier pre-dispute stage. The parties know they will be negotiating over a chair against the backdrop of the power of that appointing authority, typically to establish a short list or choose a chair. 
Third, unlike commercial arbitration between private parties, ISDS frequently involves issues of public interest and taxpayer liability for any damages. The amounts of public money at stake, in damages claims, awards and arbitration costs, may be likely to attract public attention including on adjudicator compensation arrangements.

Fourth, investment treaties with investor-state arbitration constitute general long-term government offers to arbitrate with a particular but broad class of potential claimants. A general and long-term offer to arbitrate, as opposed to a specific contract agreement to arbitrate, may mean less detailed input into individual proceedings, less ability to influence the evolution of practices over time and less ability to respond to such evolution. Exit from a treaty or from an appointing authority/arbitration institution may be a more drastic move than a change of contracting approach to arbitration clauses, particularly if it may be portrayed by some as reflecting a broad anti-foreign investment policy. Correspondingly greater power may be given to arbitration market participants, which may affect perceptions about the likely impact of any compensation-related incentives over time.

Fifth, while still limited in practice, some aspects of ISDS are more transparent than commercial arbitration, particularly under some treaties. The strong public and professional interest in information about the system has generated products ranging from specialised news services to case information databases which seek out and disclose additional information. Remaining significant gaps in information, including about compensation, may be more likely to draw public attention, especially in light of strong disclosure standards for compensation of the domestic judiciary.

Sixth, investment arbitration decisions have more future consequences than commercial arbitration awards. Most commercial arbitration awards are not published. Even where commercial arbitration awards are public, the merits generally turn on terms of specific contracts and events. The contract at issue in each case is generally different. In contrast, ISDS disputes generally involve the same limited range of treaty provisions. ISDS decisions are more frequently public; they are regularly cited by disputing parties on issues of substance, remedies, procedure and other matters. The repetitive nature of a relatively small number of investment law issues increases the relevance of precedent in practice. Greater future consequences of decisions, especially on issues of government liability, may attract greater attention to the potential impact of compensation structures on those decisions.

Seventh, the political aspects of investment treaty issues may also increase the salience of compensation issues. In commercial arbitration, there is generally consensus about basic principles of contract law and the importance of the enforceability of contracts. Investment arbitration more frequently involves contentious issues about the balance between investor protection and the right to regulate on which there can be considerable political debate. ${ }^{107}$

Eighth, at the least for the bulk of commercial arbitration cases, which involve private parties, the logic and consequences of at least some expansive approaches to arbitral jurisdiction appear to differ from the issues in ISDS in many cases. The jurisdictional scope of private commercial arbitration is often seen as having expanded over the past 30 years. The expansion has been driven to a significant degree by the principles of party autonomy and a presumed interest of private parties in having related issues resolved in a single proceeding. 
Decisions on jurisdiction in ISDS can raise different considerations because it is the agreement of the treaty parties - not the disputing parties -- that determines the scope of jurisdiction. Decisions for example about whether particular investments are covered investments do not involve presumed or actual disputing party intent to have a single proceeding. ISDS is widely recognised to be a form of international judicial review -- what is at issue is the scope of international review of government action.

These factors may generate greater public interest in compensation arrangements for adjudicators in ISDS than in commercial arbitration. They may also produce higher public expectations about the need for institutional independence and impartiality of adjudicators.

\section{Conclusion}

A better understanding of domestic court approaches on key institutional issues can help inform consideration of possible work on those issues in ISDS whether by way of institutional reforms, government-developed codes of conduct, rules on disclosure, adjudicator selection criteria or other approaches. It may assist governments in assessing the costs and benefits of different institutional arrangements. And it may help in the process of improving domestic courts themselves, a frequent treaty policy goal, but also advanced by some as an alternative to treaties.

Complaints about generalised economic incentives of judges in legal systems in advanced economies are rare. In contrast, while there is no generally accepted view, such complaints have become an important component of criticism about a perceived lack of impartiality and conflicts of interest in ISDS. In 2014, the OECD Secretary-General set out his views on a reform agenda for investment treaties that took note of the achievements in domestic law and encouraged attention to the issue in ISDS: "Advanced domestic systems for settling disputes between investors and governments go to great lengths to avoid the appearance of economic interests influencing decisions. Investment arbitration needs to do the same."108

Beyond issues of legitimacy and public confidence, adjudicator incentives can also be a consideration for institutional design and desired outcomes. The economic incentives created by litigant fees as opposed to salaries can be seen as pulling in opposite directions on adjudicator approaches to jurisdiction. There are of course many other factors that may also affect adjudicator attitudes. 


\section{Annex 1: \\ 2016 OECD Investment Treaty Conference discussion relating to adjudicator compensation}

The 2016 OECD Investment Treaty Conference topic was "The quest for balance between investor protection and governments' right to regulate". ${ }^{109}$ Governments and others discussed a range of issues. The discussion confirmed that economic considerations in adjudication and adjudicator compensation are important issues in policy debates over ISDS. At the same time, limited time in the context of a more general Conference meant that views on issues related to adjudicator compensation were briefly stated. They are set out here for background.

The EU provided a general description of its proposed Investment Court System ("ICS") and addressed compensation issues only briefly. It pointed to a loss of public trust in the ad hoc commercial arbitration model for ISDS among a large proportion of EU citizens and policy makers following broad and intensive debate, including a public consultation. They have lost trust in the existing arbitration system; they no longer accept that claims that can involve issues of great public importance and high monetary stakes can be resolved by an arbitration system derived from commercial arbitration. The EU is thus proposing a system with a stronger public law dimension to resolve treaty issues, one that operates in similar way to other international courts and tribunals. It underlined the need for guarantees of strict independence and noted that the ICS provides for limits on procedural costs and stricter time lines.

The US pointed to the need for reforms to be based on a thorough understanding of how the current system works. This view was echoed by the United States Council for International Business (USCIB). The US expressed concern about the presentation of a new standing dispute settlement mechanism as being necessary to achieve impartiality, quality of arbitrators and neutrality. It stated that this seems to presume that absent that reform there is a crisis with regard to those three elements, a view which the US contests. It noted that the current rules require disclosure of information by arbitrators and provides opportunities for challenge to an arbitrator, which are increasingly used. Applicable ethical principles include the International Bar Association (IBA) Guidelines plus individual arbitrators can be subject to rules as attorneys. The US stated that this allows challenges if arbitrators lack independence.

The American Federation of Labor-Congress of Industrial Organizations (AFL-CIO) stated that the known facts clearly established a need for reform. The US clarified that it recognises that there are many legitimate concerns and questions about ISDS but in responding it is important to factually interrogate what the concerns are. It considered that there are often two aspects: (i) what the rules are, whether there are deficiencies or changes needed - this involves a legal response; (ii) how do you communicate how the rules actually work? The US stated that there is a difference between conflicts of interest and perceptions of conflicts of interest. It considered that it is important to identify the problems we want to fix and how we can improve things. It stated that to the extent some concerns are based on misunderstandings and misapprehension about how arbitration works, it is equally important that we communicate about the facts.

The discussion also addressed issues of impact of economic considerations. Peru stated that statistics are needed relating to alleged shortcomings in investor-state arbitration. It asked why, if the system is

109

OECD, The quest for balance between investor protection and governments' right to regulate (March 2016). The detailed agenda of issues addressed is available on the Conference webpage. 
biased, investors do not win every time. It stated that UNCTAD statistics show that states win most cases. AFL-CIO stated that any suggestion that the system is acceptable because investors do not always win sets a very low standard. It stated that the win/lose numbers are roughly $1 / 3$ investor, $1 / 3$ government, $1 / 3$ settled. It stated that the third that is settled often involves payment or regulatory change so it can be considered that the government has lost $2 / 3$ of the cases. It stated that more broadly, the whole system involves claims on governments; there is no way for them to win, only to lose more or to lose less.

Professor Howse referred to investor-state arbitration as an "expensive, often very delayed, complex way of solving investment disputes". He described it as "essentially run by a self-referential clique, [with] very little accountability to anyone outside that clique, that has turned it into an enormous cash cow". AFLCIO agreed with the "cash cow" characterisation for investor-state arbitration, stating that "a small group of people have made a lot of money [and have] a personal interest in maintaining and accelerating the system." AFL-CIO referred to investor-state arbitration as "outrageously biased" with inherent conflicts of interest. Conflicts of interest include individuals moving back and forth between serving as arbitrators and representing companies.

As noted, the EU presented the ICS as a new model. Japan noted that it shared the view that important ISDS improvements are necessary. It agreed that there is a need for more legitimacy and public confidence, but it stated that recognition of a disease does not lead to the conclusion that the investment court approach is the right medicine. Japan noted that many issues invited discussion, but it focused on one specific point, fairness. It questioned whether the system would be sufficiently fair and would appear sufficiently fair to obtain legitimacy and confidence.

Japan noted that the May 2015 EU concept paper pointed to issues of real and perceived conflicts of interest due to arbitrators engaging in work as counsel. Japan applied this standard to the ICS. It noted that CETA calls for tribunal members to be paid a monthly retainer fee by Canada and EU, and that the amount is not stipulated in CETA. Japan considered that it would have to be high enough to compensate for loss of other work as counsel or expert. It considered that otherwise, first class lawyers would not agree to serve. Japan questioned whether such a high amount would constitute an actual or perceived conflict of interest.

Japan also pointed to provisions for re-election of tribunal members after their initial term. It noted that a tribunal member would lose income if he or she is not re-elected by the Joint Committee after a first term. ${ }^{110}$ It suggested some might think that a person who decides against a state will not be re-elected by the Joint Committee. Japan questioned whether that this would be interference with the ability of tribunal members to act independently and to properly balance investor protection with the right to regulate.

Japan also quoted (i) the Code of conduct in the draft EU-Singapore Free Trade Agreement, paragraph 11, which provides that "[a]n arbitrator shall not directly or indirectly enter into any obligation or accept any benefit that would in any way interfere or appear to interfere with proper performance of his or her duties"; and (ii) footnote 10 of the CETA ISDS chapter which provides that "for greater certainty, the fact that a person received remuneration from a government does not in itself make that person ineligible". Japan expressed uncertainty about how those two rules could be compatible.

Japan also noted the comments on a particular case in the concept paper. It described a hypothesis where in that case, all, not one, of the tribunal members were selected from a list prepared only by the investor claimant, they were liberally paid only by the investor and they had feared such payments could be stopped if they ruled against the investor. Japan asked if we could we call such a tribunal fair, or more

110 The CETA Joint Committee, an intergovernmental committee, is to be composed of representatives of each Party and "co-chaired by the Minister for International Trade of Canada and the Member of the European Commission responsible for Trade, or their respective designees.” (CETA art. 26(1)). 
precisely, if we could consider that it appears fair? It stated that if not, the opposite system, under the full control of the states would also not appear fair and it could not obtain legitimacy and confidence. The European Federation for Investment Law and Arbitration (EFILA) also suggested that nomination and payment of judges by states would establish a pro-state court. Japan suggested that the appropriate answer is to develop an appropriate rules of conduct as the Parties are doing in TPP. If an arbitrator fails to follow the rules, he or she would be justifiably disqualified or the award could be annulled.

Prof. Howse responded to the points about government appointment and payment of judges (although he referred to government appointment without specifically referring to payment). He stated that it would be bizarre if a claimant challenging an EPA [Environmental Protection Agency] regulation in front of the Second Circuit federal appellate court in the United States were to ask for its own judge. He suggested that no public law system law in the world allows a claimant challenging government action to appoint its own judge. In his view, that is not how public law is carried out. He stated that the broad academic literature on government-nominated courts like the European Court of Human Rights (ECtHR) or the Inter-American Court of Human Rights criticises them for, if anything, excessively broad approaches to allowing claims against governments. In his view, there was no basis whatsoever to consider that government nomination of judges would give rise to a pro-state court.

The EU stated that the ICS is seeking to get away from a system where the payer of an adjudicator is seen as having influence over that adjudicator. The goal is to create a group of independent judges. Governments select and pay all of the judges on many courts that are seen as independent, such as the ECtHR.

Japan recognised that the ECtHR is a successful court and it did not challenge its impartiality. Japan stated, however, that the starting point is different. It stated that the ECtHR is purely individual and addresses how to restrict the absolute power of the state. It stated that in the ICS, the starting point is a pure state point, the issue is how to control the power of investors. Japan stated that this did not mean that the ICS would never be a good court like the ECtHR, but there is a risk and a problem of appearance of partiality. It asked why we should we take that risk. It agreed with the US statement that the current system already contains mechanisms for impartiality and transparency. It stated that governments are doing more in codes of conduct and in the UNCITRAL transparency rules. It asked why a court system is suggested as the only and essential answer.

Prof. Howse considered that the ICS usefully introduces time limits and limits on costs for the first time. He stated that the time for a full first instance and appeal procedure under the ICS would be a year less than a typical investor-state arbitration. He stated that "[b]ecause [in investor-state arbitration] everyone is on the clock ... at 1500 USD or GBP, of course there is extensive judicial wrangling" with lengthy procedural or jurisdictional questions "that a US federal judge ... would decide in ten minutes ... the problem is that everyone is getting rich."

Critics of investor-state arbitration generally stated that the ICS was an important effort to address issues of conflicts of interest and would be a significant advance in that area. Most, however, considered that the ICS changes to dispute settlement were not sufficient to garner their support for the investment treaty system due to other perceived deficiencies including access limited to foreign investors and unbalanced obligations. 


\section{Annex 2: \\ Preliminary review of facts relating to compensation of adjudicators and dispute settlement administrators in ISDS}

There is relatively little information about the economics of compensation of adjudicators in ISDS. There is no systematic disclosure of information about cases or costs associated with ISDS. No aggregate information can be collected. There has been no detailed parliamentary or other inquiry into fee-based compensation in ISDS analogous to the 1798 UK House of Commons Finance Committee report or subsequent parliamentary reports of that era. The ISDS scoping paper noted the limits on available information, but engaged in some analysis based on available information. ${ }^{11}$

Compensation related aspects in the organisation of the ICS in CETA are also addressed based on available information.

\section{A. In investor-state arbitration}

\section{Arbitrators}

The preliminary fact-finding here is limited to the narrow issue of the direct impact on arbitrator compensation of certain decisions in individual cases. As governments have noted, a number of additional interests may exist beyond the impact in the individual case, including the scope of claims in the future or marketability as an arbitrator, expert or counsel in the future. The issue of the scope of parallel work as, for example, counsel or an expert, is not addressed. Those issues raise broader empirical questions.

Direct financial consequences exist for decisions on jurisdictional issues where they are resolved separately in bifurcated proceedings. A decision denying jurisdiction ends the proceeding whereas a finding of jurisdiction leads to further proceedings on the merits and damages. Similar consequences also apply to decisions on other preliminary issues that could terminate or significantly narrow a case, such as a finding that a claim has no legal basis in light of the treaty.

Direct financial consequences also exist for decisions to postpone jurisdictional or other potential case-terminating objections until the merits are also addressed. Some treaties now permit governments to compel separate arbitral consideration of jurisdictional or certain other issues early in the case.

It appears that all disputes over jurisdiction in ISDS have involved an investor claimant seeking a broader reading while a government seeks a narrower one. It is possible to quantify in rough terms the average amount of fees and expenses at issue in decisions over jurisdiction. The ISDS Scoping paper noted research suggesting that arbitrator fees and expenses account for approximately $16 \%$ of arbitration costs and arbitration institutions account for $2 \%$. (The remaining $82 \%$ represent the parties' legal and expert costs.). ${ }^{112}$

\footnotetext{
111 David Gaukrodger \& Kathryn Gordon (2012), "Investor-State Dispute Settlement: A Scoping Paper for the Investment Policy Community”, OECD Working Papers on International Investment, 2012/03.

112

Id., p.19.
} 
ISDS case costs were found to average approximately USD 8 million based on the limited available information and have reportedly increased since then. Taking the USD 8 million number as a conservative estimate, average arbitral fees and expenses amount to USD 1.28 million per case. For a three-person tribunal, this amounts to an average of roughly USD 427,000 per arbitrator per case.

The distribution of work between jurisdictional and merits stages varies. If it is conservatively estimated that the merits account for half the fees and expenses in a case, preliminary decisions on jurisdiction would determine whether the arbitrator has the opportunity to earn USD 213,500 in fees (less expenses) for additional work on the merits.

Arbitrator fees vary depending on the arbitration forum. They are generally freely negotiated by the arbitrator and the nominating party or entity in non-ICSID cases. In ICSID, they are generally capped at USD 3000 a day and this limit has been monitored by the ICSID Secretariat since 2006 following concerns about post-appointment renegotiation of fees in some cases. ${ }^{113}$

The differences between ICSID and non-ICSID cases appear to be substantial. ICSID's cap is equivalent to USD 375/hour. The Economist refers to fees of USD 600-700 and higher fees are sometimes cited. The differences could give rise to an arbitral preference for non-ICSID arbitration. As noted in the ISDS Scoping paper, "an investor's forum-selection options, where they exist under an investment treaty, may be a relevant consideration to a potential investor-appointed arbitrator because the different fora apply different rules and pay different fees". ${ }^{114}$ It is unclear if this is discussed in fee discussions between investors, their counsel and potential co-arbitrators, which may take place before the investor chooses its forum in ISDS.

In the 2012 Roundtable public consultation on ISDS, a global law firm responded to a general question about economic interests of arbitrators, stating that "[i]t is unclear whether the ISDS system in fact creates economic incentives that could affect arbitrators' conduct. This is because compensation for arbitrators is not necessarily greater than compensation that an attorney might receive when serving as counsel in private practice." ${ }^{115}$ Given billing rates for partners at major corporate law firms and their capacity to manage large teams of more junior lawyers and staff in work for clients, it appears likely that for some arbitrators alternative work would generate significantly higher remuneration (especially in comparison with the ICSID rate).

At the same time, a response to concerns about institutional economic incentives in ISDS that relies on arbitrators generally having better alternative offers than USD 600-700/hour (or USD 3000/day) might not address all public concerns about incentives and might be difficult to empirically establish as a general matter. Suggestions that all arbitrators have access to this type of alternative employment might also exacerbate concerns about the composition of the pool of adjudicators for cases involving public interests. It appears that lower rates of compensation may modify or diversify the pool of adjudicators in systems based on mid-career appointment. As US judicial salaries have fallen far behind private sector lawyer income, the pool of federal judges has incorporated more judges with previous public sector experience. ${ }^{116}$

113 David Gaukrodger \& Kathryn Gordon (2012), “Investor-State Dispute Settlement: A Scoping Paper for the Investment Policy Community”, OECD Working Papers on International Investment, 2012/03, p. 20 n.26.

$114 \quad$ Id. at 20.

115 OECD, Investor-State Dispute Settlement Public Consultation: 16 May - 23 July 2012: Comments received as of 30 August 2012 , p. 40.

116 Chief Justice John Roberts, 2006 Year-End Report on the Federal Judiciary, (1 Jan. 2007); Hearing on Judicial Security and Independence Before the S. Comm. on the Judiciary, 109th Cong. (2007) 


\section{2. $\quad$ Appointing authorities and arbitration institutions}

Based on the USD 8 million conservative average case costs figure, average administrative fees per case amount to USD 160,000. Billing approaches vary between the different institutions. Some appear to use a flat fee based on the size of the claim while others bill on a per hour basis.

Appointing authorities and dispute settlement administrators have grown substantially with the growth of ISDS. For example, ICSID today consists of about 70 staff, who administer arbitration and conciliation cases at ICSID and support other ICSID activities. The staff has grown by $350 \%$ since 2004 and by almost $100 \%$ since $2010 .{ }^{117}$ ICSID's case load is primarily composed of investment treaty cases.

The number of PCA Secretariat staff has grown by almost $500 \%$ since 2005 and by $100 \%$ since 2010 , to a total of 75 in $2015 .{ }^{118}$ Over half of current PCA cases are ISDS cases. ${ }^{119}$

Further research will address the private appointing authorities/arbitration institutions that primarily serve the commercial arbitration market but that are increasingly demonstrating interest in ISDS. This includes the Arbitration Institute of the Stockholm Chamber of Commerce, the International Chamber of Commerce as well as apparently newer entrants such as the Singapore International Arbitration Centre which released special Investment Arbitration Rules on 1 January 2017.

\section{B. In the investment court system (ICS)}

The CETA sets out a number of provisions relating to compensation but leaves a range of issues for future determination:

- The CETA Parties have flexibility to address through Joint Committee decisions certain aspects of the compensation arrangements for first-instance tribunal members. The Joint Committee, an intergovernmental committee, is to be composed of representatives of each Party and "co-chaired by the Minister for International Trade of Canada and the Member of the European Commission responsible for Trade, or their respective designees.” (art. 26(1)).

- The Joint Committee will appoint the 15 members of the first-instance tribunal for a renewable five-year term. (art. 8.27(2)). In the first instance, the Joint Committee will fix a monthly salary (retainer) paid for by the Parties.

- First-instance tribunal members active in a three-person division hearing a case will also receive case fees and expenses from the disputing parties. Case fees and expenses for members are fixed at the ICSID level (currently USD 3000 day plus expenses) unless the Joint Committee decides

\footnotetext{
${ }_{117}$ Growth has been steady since 2004: 20 staff members (ICSID, Annual Report 2004, p. 2); $2006: 26$ staff members (ICSID, Annual Report 2006, p. 2); 2008: 30 staff members (ICSID, Annual Report 2008, p. 2); 2010: 35 staff members (ICSID, Annual Report 2010, p. 2); 2012: 45 staff members (ICSID, Annual Report 2012, p. 2); 2014: 54 staff members (ICSID, Annual Report 2014, p. 2, 3); 2016: 67 staff members (ICSID, Annual Report 2016, p. 52).

In 2005, the number of staff was 16 (PCA, Annual Report 2005, p. 19), in 2010, staff numbered 37 (PCA, Annual Report 2010, p. 19), and staff had grown to 75 by 2015 (PCA, Annual Report 2015, p. 40 et seq.).

The PCA 2015 Annual Report (p. 8) states that during 2015 it administered 135 cases, 42 of which were initiated in 2015. Of the 135 cases administered during 2015, 76 were ISDS cases arising under bilateral/multilateral investment treaties and national investment laws and 44 were cases arising under contracts involving a State, intergovernmental organization, or other public entity.
} 
otherwise. The division will allocate those case costs between the disputing parties as part of its award.

- The compensation system can be transformed into a regular salary rather than the retainer and case fees model by Joint Committee decision. (art. 8.27(15)) The Joint Committee will also decide on the compensation regime for the appellate tribunal.

The basic initial structure for the first instance tribunal involves a mix of salary and per day fees payable by litigants. Litigant fees would be substantial, equivalent to the ICSID level. If hypothetically converted for purposes of comparison into annual salaries based on steady work, the fee rate would be significantly higher than the salaries of the highest paid domestic judges. ${ }^{120}$ As noted above, the ICSID fee rate is considerably lower than the open market billing rates of some arbitrators.

The discussion above notes that preliminary research suggests that judges in advanced economies are appointed for life or for significant fixed terms with a possibility of re-appointment. Further factual analysis would allow more detailed comparisons to the five year renewable term in CETA.

As noted above in the discussion of the creation of the US Supreme Court, one of the issues faced in creating a new salary-based court is expected case flow and budget for salaries. The EU and Canada have proposed a plurilateral court structure applicable to a greater number of investment treaties. A plurilateral court would likely have a greater case flow than a bilateral court which could facilitate the introduction of salaries, subject to working out financing arrangements.

CETA contains specific incompatibility provisions for adjudicators. Members of the first-instance tribunal are barred from serving as counsel, party-appointed expert or witness in any pending or new investment dispute under CETA or any other international agreement. Other work as an adjudicator or arbitrator would appear to be possible. The incompatibilities appear to be close to domestic standards in advanced economies with the exception of permitted service as an arbitrator. This aspect may reflect an uncertain case flow. It would appear to differ from domestic standards for senior courts that bar judges from parallel service as an arbitrator.

Particularly for those who would be affected by the rules on incompatibilities, such as private sector arbitration counsel or professors who frequently serve as expert or counsel, expected case flow would affect the attractiveness of positions. If a standing tribunal has significant flow of cases after a period, incentives to join from this group could be affected. There is considerable debate and uncertainty about expected future case flow under investment treaties, as noted in earlier Roundtable work on balancing. ${ }^{121}$ There has also been considerable evolution of key provisions in recent treaties, including in CETA, partly in response to public concerns, which may significantly affect future case flow.

\footnotetext{
120 Assuming 45 weeks of work at 40 hours a week, the ICSID rate would amount to an annual salary of USD 675 000. That is substantially more that the top domestic court judge salaries. As noted above, recent reports indicate the following salaries for Supreme Court judges in France (116 751 €), Germany (110 $011 €$ ), UK- England and Wales (€ 256,206 - 2012 data) and the United States (USD 263,300).

David Gaukrodger, The balance between investor protection and the right to regulate in investment treaties: A scoping paper, OECD Working Papers on International Investment, 2017/02, pp. 19-21.
} 


\title{
OECD Working Papers on International Investment
}

\author{
www.oecd.org/investment/working-papers.htm
}

2017

$2017 / 4$

$2017 / 3$

$2017 / 2$

2017/1

2016

2016/3

$2016 / 2$

2016/1

2015

$2015 / 3$

$2015 / 2$

$2015 / 1$

2014

2014/3

$2014 / 2$

2014/1

2013

2013/4

$2013 / 3$

2013/2

2013/1

2012

$2012 / 3$

$2012 / 2$

$2012 / 1$

2011

2011/2

$2011 / 1$

2010

2010/3

$2010 / 2$

$2010 / 1$

2006

2006/4

2006/3

$2006 / 2$

$2006 / 1$

Have currency-based capital flow management measures curbed international banking flows?

Addressing the balance of interests in investment treaties: The limitation of fair and equitable treatment provisions to the minimum standard of treatment under customary international law

The balance between investor protection and the right to regulate in investment treaties: A scoping paper

Foreign direct investment, corruption and the OECD Anti-Bribery Convention

State-to-State dispute settlement and the interpretation of investment treaties

Investment policies related to national security

The legal framework applicable to joint interpretive agreements of investment treaties

Currency-based measures targeting banks - Balancing national regulation of risk and financial openness

Investment Treaties over Time - Treaty Practice and Interpretation in a Changing World

The Policy Landscape for International Investment by Government-controlled Investors: A Fact Finding Survey

Investment Treaties and Shareholder Claims: Analysis of Treaty Practice

Investment Treaties and Shareholder Claims for Reflective Loss: Insights from Advanced Systems of Corporate Law

Investment Treaty Law, Sustainable Development and Responsible Business Conduct: A Fact Finding Survey

Temporal validity of international investment agreements: a large sample survey of treaty provisions

Investment treaties as corporate law: Shareholder claims and issues of consistency

Lessons from Investment Policy Reform in Korea

China Investment Policy: an Update

Investor-state dispute settlement: A scoping paper for the investment policy community

Dispute settlement provisions in international investment agreements: A large sample survey

Corporate greenhouse gas emission reporting: A stocktaking of government schemes

Defining and measuring green FDI: An exploratory review of existing work and evidence

Environmental concerns in international investment agreements: a survey

OECD's FDI Restrictiveness Index: 2010 Update

Foreign state immunity and foreign government controlled investors

Intellectual property rights in international investment agreements

OECD's FDI regulatory restrictiveness index: Revision and extension to more economies Interpretation of the Umbrella Clause in Investment Agreements

Investor-State Dispute Settlement in Infrastructure Projects

Improving the System of Investor-State Dispute Settlement: An Overview 
2005/3 Corporate Responsibility Practices of Emerging Market Companies - A Fact-Finding Study

2005/2 Multilateral Influences on the OECD Guidelines for Multinational Enterprises

2005/1 Transparency and Third Party Participation in Investor-State Dispute Settlement Procedures

2004

$2004 / 6$

2004/5

2004/4

$2004 / 3$

2004/2

2004/1

2003

$2003 / 2$

2003/1

2002

$2002 / 2$

2002/1

2001

$2001 / 6$

2001/5

2001/4

$2001 / 3$

2001/2

2001/1

2000

$2000 / 5$

2000/4

2000/3

$2000 / 2$

2000/1

1999

1999/3 Rules for the Global Economy: Synergies between Voluntary and Binding Approaches

1999/2 Deciphering Codes of Corporate Conduct: A Review of their Contents

1999/1 Southeast Asia: the Role of FDI Policies in Development

1998

Mobilising Investment for Development: Role of ODA - The 1993-2003 Experience in Vietnam

ODA and Investment for Development: What Guidance can be drawn from Investment Climate Scoreboards?

Indirect Expropriation and the Right to Regulate in International Investment Law

Fair and Equitable Treatment Standard in International Investment Law

Most-Favoured-Nation Treatment in International Investment Law

Relationships between International Investment Agreements

Business Approaches to Combating Corrupt Practices

Incentives-based Competition for Foreign Direct Investment: The Case of Brazil

Managing Working Conditions in the Supply Chain: A Fact-Finding Study of Corporate Practices

Multinational Enterprises in Situations of Violent Conflict and Widespread Human Rights Abuses

Codes of Corporate Conduct: Expanded review of their contents

The OECD Guidelines for Multinational Enterprises and other corporate responsibility instruments

Public policy and voluntary initiatives: What roles have governments played?

Making codes of corporate conduct work: Management control systems and corporate responsibility

Corporate Responsibility: Results of a fact-finding mission on private initiatives

Private Initiatives for Corporate Responsibility: An Analysis

Recent trends, policies and challenges in South East European countries

Main determinants and impacts of FDI on China's economy

Lithuania: Foreign Direct Investment Impact and Policy Analysis

Investment Patterns in a Longer-Term Perspective

Bribery and the business sector: Managing the relationship

1998/1 Survey of OECD work on international investment 